\title{
Beneficiation and Physiochemical Characterization of Coal Deposits in Achibo-Sombo Area, South- Western Ethiopia
}

\section{Temam Usman}

Addis Ababa Science and Technology University

\section{Samuel Abicho}

Addis Ababa Science and Technology University

Daniel Meshesha

Addis Ababa Science and Technology University

Getachew Adam Workneh ( $\nabla$ getachew.adam@aastu.edu.et)

Addis Ababa Science and Technology University https://orcid.org/0000-0002-2863-1379

\section{Research}

Keywords: Achibo-Sombo, Beneficiation, Coal, Physiochemical characterization, Froth floatation

Posted Date: April 6th, 2021

DOl: https://doi.org/10.21203/rs.3.rs-389408/v1

License: (c) (i) This work is licensed under a Creative Commons Attribution 4.0 International License.

Read Full License 


\title{
Beneficiation and Physiochemical Characterization of Coal Deposits in Achibo-Sombo Area, South-Western Ethiopia
}

Temam Usman ${ }^{1}$, Samuel Abicho ${ }^{1}$ Daniel Meshesha ${ }^{2}$ and Getachew Adam Workneh*1

${ }^{1}$ Sustainable Energy Centre of Excellence, Department of Industrial Chemistry, College of Applied Science, Addis Ababa Science and Technology University, P.O. Box 16417, Addis Ababa, Ethiopia

${ }^{2}$ Mineral Exploration, extraction and processing Centre of Excellence, Department of Geology, College of Applied Sciences Addis Ababa Science and Technology University, P.O. Box 16417, Addis Ababa, Ethiopia

*Corresponding author Email: getachew.adam@aastu.edu.et

\begin{abstract}
This study was conducted to upgrade the quality of Achibo-Sombo coal deposits by physiochemical beneficiation methods particularly by using froth floatation technique to minimize the ash and sulfur content from coal particles. During the floatation test, proximate, ultimate, calorific value, functional groups, surface morphology and crystal structure analysis of Achibo-Sombo coal was carried out through different methods. The moisture content of a raw sample and treated sample is found in the range of 11.81 to $20.27 \%$ and 8.12 to $14.02 \%$ respectively. The volatile matter is ranging from 22.74 to $34.85 \%$ for raw coal and 21.92 to $30.64 \%$ for treated coal samples. The ash content of the raw coal sample is ranging from 22.47 to $36.58 \%$ which became in the range 7.49 to $13.62 \%$ after treatment. The fixed carbon is also changed from $23.85-38.31 \%$ of raw sample to $44.47-55.87 \%$ for treated coal samples. The calorific value of a raw sample is found in the ranges of $5838.46 \mathrm{Btu} / \mathrm{lb}$. to $9531.29 \mathrm{Btu} / \mathrm{lb}$. whereas for treated coal samples it is found in the ranges of $9438.12 \mathrm{Btu} / \mathrm{lb}$. to $11756.63 \mathrm{Btu} / \mathrm{lb}$. The sulfur and nitrogen contents of the raw coal sample which were ranged from 0.57 to $1.9 \%-1.22$ to $1.44 \%$ are reduced to 0.25 to $0.41 \%-0.52$ to $0.92 \%$ respectively after treatment. Generally, the Achibo-Sombo raw coal is falling under the coal grade of lignite B to sub-bituminous B whereas the treated coal sample is grouped under sub-bituminous C to high volatile bituminous C. Accordingly, the results obtained indicate that the Achibo coal streams are upgraded relatively with better calorific value and fixed carbon and with lowest ash contents as compared to samples collected from other sites.
\end{abstract}

Keywords: Achibo-Sombo, Beneficiation, Coal, Physiochemical characterization, Froth floatation

\section{Introduction}

Coal is an organic fossil fuel and sedimentary rock that contains carbon, oxygen, hydrogen, sulfur, nitrogen, and trace elements as a mineral matter in pore systems of the coal (Wakuma and Assaba 2017; Rao and Anuradha 2019). Coal is formed through the coalification process in which plant debris were transformed from the peat to lignite and then through the higher ranks of coal to anthracite (Speight 2015). According to American society testing and materials (ASTM D-388) standards, coal is classified into four types as lignite, bituminous, sub-bituminous and 
anthracite (Ruiz et al.2019). Coal is used as an energy source in industry like cement and metallurgical factories due to its higher energy density than other energy sources (Abraham 2017; Liu etal.2018). Cement industries use coal as an energy source to burn the raw materials with high temperature $\left(1450{ }^{\circ} \mathrm{C}\right.$ ) in a kiln and metallurgical (steel or iron ) industries are also used coal for the smelting of iron with high temperature (Abraham 2017; Demoze 2016).

It is estimated that nearly two-thirds of energy supplies from coal resources comes from China. (Wakuma and Assaba 2017; Liu et al.2018; Ikwuangu et al.2017). The largest top five coal-producing countries are USA, China, Australia, India and South Africa. Countries like Australia, Indonesia, Russia, South Africa and China use coal exporting to get foreign exchanges (Demoze 2016). Commercially coal is mined in more than 50 countries and about 70 countries are using coal. The world Annual consumption of coal is about 5,800 million tons per year, out of this about $75 \%$ is used for the generation of energy and the rest $25 \%$ is used for the manufacturing of different industrial products (Abraham 2017; Mishra et al.2015).

The availability of coal resources in Ethiopia is estimated to be around 300 million tons. It is widely distributed in the country particularly in Northern (Chilga basin), South-Western (Delbi-Moye, Yayo (Wittete, Achibo-Sombo, Dabaso \& kumbabe), Nejo and Arjo basin) and Central Plateau of Ethiopia (Mush valley Basins, Wuchale) (Abraham 2017; Ahmed 2008; Haftu et al. 2019). The Ethiopian coal is characterized by high impurity which does not fulfill the requirements for desired applications. $t$ it has high amounts of ash and sulfur which causes environmental pollution, and very low carbon content and calorific values (Demoze 2016; Dejene 2004).

The major environmental impact of coal combustion is related to the emissions of particulate gases into the atmosphere. During combustion, the elements in coal are converted to their particular oxides in the form of gaseous or aerosols (liquid droplets) and adsorbed by particulates (fly ash) and continued through flue gas stream as emissions. The emitted gases include sulfur oxides ( $\mathrm{SOx}$ ), water vapor, carbon dioxide $\left(\mathrm{CO}_{2}\right)$, nitrogen oxides (NOx), and compounds and elements that are identified as hazardous air pollutants (HAPs) such as mercury and arsenic leading to the major challenges of coal utilization (Ruiz et al.2019; Singh 2016).

Therefore, to solve these problems different researchers have tried to develop beneficiation technology to minimize the impurity of coal so that it fits with its application requirements (Mishra et al 2015; Liu et al.2018; Behera et al.2018). Coal beneficiation is the process of improving the carbon number to increase the calorific value of the coal by removing the inert material (mineral matters). The main purpose of beneficiation of low grade coal is, to reduce the inert particle of mineral matter, to improve the combustion behavior, for reducing slagging and fouling characteristics, to minimize the capital of operating condition, to reduce the particulate pollutants and gas emission, (Behera et al.2018; Meshram et al.2015).

The techniques used for upgrading or beneficiation of low-rank coals are physical, chemical and physicochemical beneficiations (Behera et al.2018; Qu et al.2015; Barma 2019). Physical and chemical beneficiation techniques are more selective for minerals separation and they not economical in terms of cost. These techniques are less efficient and use more expensive reagents that need to be purified before discharge (Liu et al.2018; Chen et al.2018). Physiochemical beneficiation is the most cost-effective and less expensive separation of finely dispersed minerals to 
remove the inert materials based on the hydrophobicity of coal particles and hydrophilicity of mineral matters. Among the Physiochemical techniques, Froth floatation is highly economical and efficient with basic principles of surface wettability of fine coal and separation efficiency is based on the attachment of pure coal on the surface of hydrophobic oil reagents and detachment of impurities matters from the surfaces (Barma 2019; Ni et al. 2018; Wen et al.2017; Tia et al.2017). In this study upgrading of local coal (coal collected from Achibo-Sombo) through froth flotation technique was done using diesel oil as collectors and n-octanol as frother to prepare the coal for the desired application after upgrading.

\section{Experimental part}

\subsection{Description of study area}

This study was conducted at Yayo Woreda, specifically in Achibo-Sombo villages. It is located $564 \mathrm{~km}$ west of the capital city Addis Ababa on the road to Gambela in Illubabor zone, Oromia Regional States, South Western Ethiopia

(Fig. 1). It lies in between $25 \mathrm{~km}$ eastern side of Administrative towns (Mattu) and near the village (Chora distinct) $18 \mathrm{~km}$ on the western side.

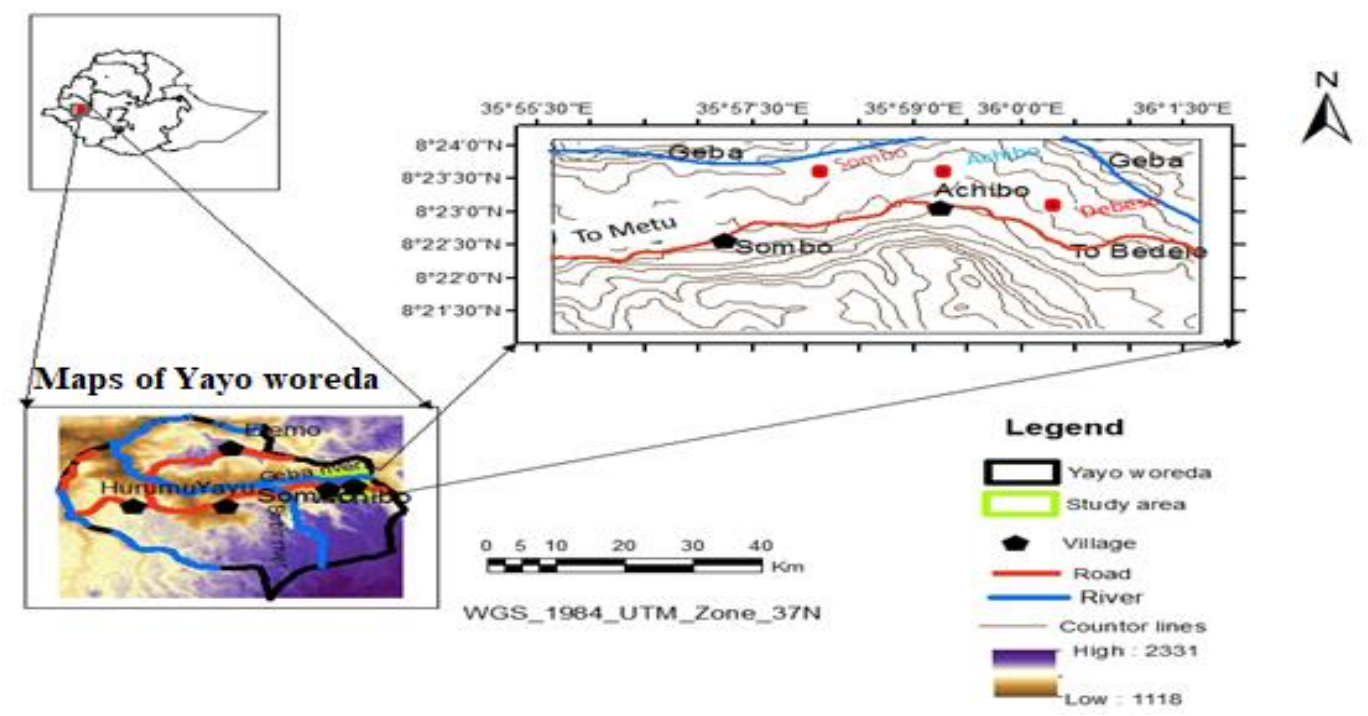

Fig. 1 Location of the study area.

The targeted area is bounded between the geographic coordinates of $8^{\circ} 21^{\prime} 30^{\prime \prime} \mathrm{N}-8^{\circ} 24^{\prime} 0^{\prime \prime} \mathrm{N}$ and $35^{\circ} 55^{\prime} 30^{\prime \prime} \mathrm{E}-$ $36^{\circ} 130^{\prime \prime}$ E latitude and longitude respectively covering an area of $9.11 \mathrm{~km}^{2}$ with elevation of $1118-2331 \mathrm{~m}$ above sea level within Geba river streams.

\subsubsection{Climate and Vegetation}

The climate condition of the study area is characterized by humid and warm tropical rainy climate with a mean minimum temperature of $13.5^{\circ} \mathrm{C}$ and maximum temperatures of $27.3^{\circ} \mathrm{C}$. The rainfall pattern of the area is with a mean annual rainfall ranging from 1243 to $3445 \mathrm{~mm}$. Therefore, such a diverse mixed climatic condition is the most important factor for the availability of a huge wealth of biologically diverse species in the area. The soil condition of the area is fertile or compatible of soil types that covered high diversity and tropical forests (natural vegetation) which are recorded on international level (UNESCO) as named by Yayo forest (IEA 2019; Wagaw 2007) 


\subsubsection{Geology of the area}

The coal deposit in the area is mined with surface mining (strip mining) systems that was more used to produce coal recoveries with a higher proportions and high efficiency. In strip mining the giant machines remove the top-soil and layers of rock to expose large beds of coal in Fig 2. Once the coal is mined the rocks and dirt things are returned into the area for replanting to be used as a cropland and, habitats of wildlife and recreation
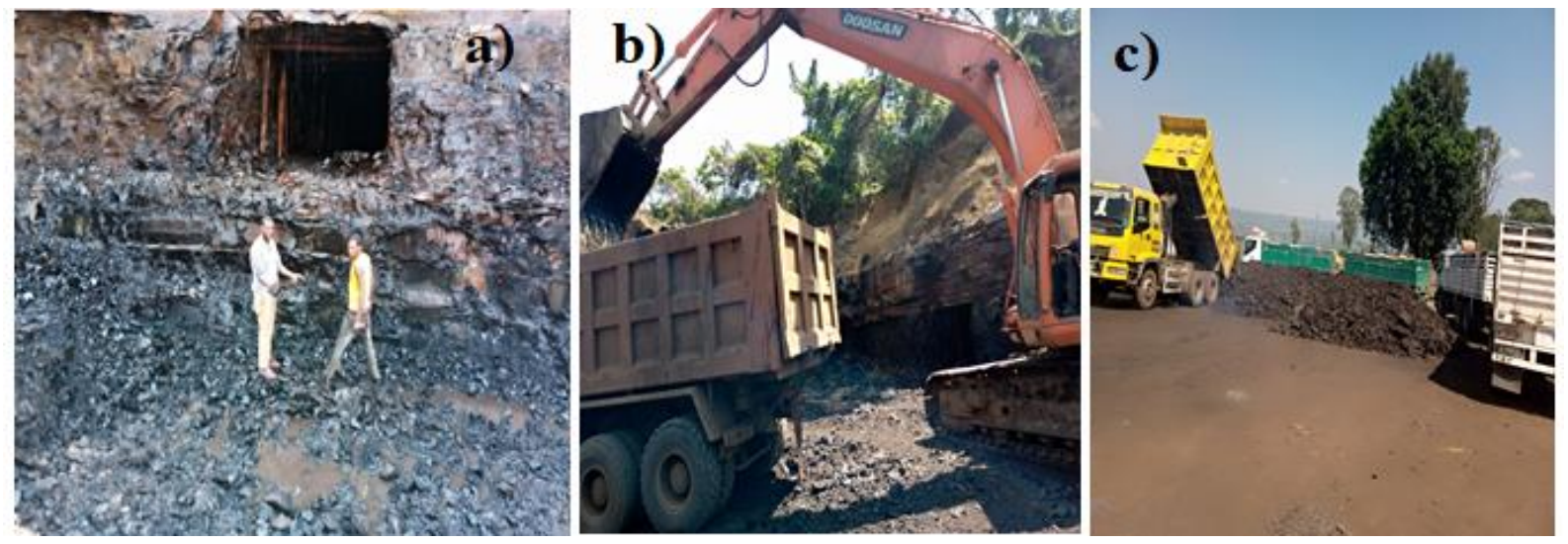

Fig. 2 The sampling area a) exploration site b) surface mining of coal deposits c) mined coal

\subsection{Materials and reagents:}

The materials that are used to conduct this study are: Muffle furnace, Jaw crusher, Centrifugal mill, Sieve Shaker, Adiabatic Bomb calorimeter, Wedag flotation, Flash CHNS/O analyzer and Kjeldahl Digester. The chemical reagents used were Diesel oil, N-Octanol (99\%), Sodium hydroxide (98\%), Sulfuric acid (98\%), Boric acid (99.5\%), Hydrochloric acid (37\%), Kjeldahl tablets $\left(0.15 \mathrm{gm}\right.$ of $\mathrm{CuSO}_{4} \& 1.5 \mathrm{gm}$ of $\left.\mathrm{K}_{2} \mathrm{SO}_{4}\right)$, Magnesium oxide, Sodium carbonate anhydrous, Tashoro's indicators (MR\& BCG).

\subsection{Flotation procedures of coal sample}

The optimized size of $125-63 \mu \mathrm{m}$ and Wedag flotation cell of $3 \mathrm{~L}$ was used to conduct this experiments. $90 \mathrm{~g}$ of the fine sample was mixed with $2.5 \mathrm{~L}$ of tap water and stirred for 3 minutes with the adjusted impeller speed of 2800 rpm until the coal particles were completely wetted by closing the air valve with scotch. Then $5 \mathrm{ml}$ rops of diesel oil were added as a collector and then agitated for again 2 minutes and $40 \mathrm{ppm}$ of $\mathrm{N}$-octanol was added as a frother and an air valve was opened to supply the air in the floatation cell condition to form the bubble particle. When bubble formation was started $0.5 \mathrm{~L}$ of water was added to fill the capacity of a cell. The formed bubble particle was started to overflow the cell and the flow particles were collected. The collected and formed foam is continued until the white foam was observed which indicates that all the solid particle in the cell are attached to the oil collectors. Finally, the collected particle was filtered and dried in a hot oven at $80^{\circ} \mathrm{C}$ and floatation concentrate yield is calculated according to Equation 1.

$$
\text { Yield }=\frac{\mathrm{Mc}}{\mathrm{Mf}} \times 100 \%
$$




\subsection{Moisture content determination}

The determination of the total moisture was according to the standards of ASTM D-3302 where $2 \mathrm{~g}$ of the air-dried fine coal sample was taken in silica crucible and gently heated in a hot oven with an experimental temperature of $107^{\circ} \mathrm{C}$ for three hours. The heated sample was then taken from the hot oven and put in a dissecator to cool the sample, then the cooled sample was reweighed and moisture content was calculated by using the formula in Equation 2.

$$
\text { Moisture content }(\%)=\frac{\text { loss in weight }}{\text { weight of sample taken }} \times 100 \%
$$

\subsection{Volatile matter determination}

The percentage of the volatile matter was determined according to the testing method of ASTM D-3175 where $1 \mathrm{~g}$ of an air-dried sample was weighed in a silica crucible which is covered with a lid to avoid oxidation of the sample. Then the sample was heated at a temperature of $950 \pm 5^{\circ} \mathrm{C}$ in a muffle furnace exactly for seven minutes in the absence of air. After heating and putting in dissecator for cooling and the sample was re-weighed again and the volatile matter was determined by using Equation 3.

$$
\text { Volatile matter }(\%)=\frac{\text { loss in weight }}{\text { weight of sample taken }} \times 100 \%-\text { moisture } \%
$$

\subsection{Ash content determination}

The amount of ash was determined based on the standard procedure of ASTM D-3174. 1g of the sample was weighed in silica crucible and heated in a muffle furnace with a temperature of $850 \pm 5^{\circ} \mathrm{C}$ without lid covers for 3 hours. After burning the residue ash was cooled in a dissecator and re-weighed again and ash content was calculated by using Equation 4.

Ash content $(\%)=\frac{\text { weight of ash residue }}{\text { weight of dried coal sample }} \times 100 \%$

\subsection{Fixed carbon determination}

The percentage of fixed carbon of coal sample was determined according to ASTM D-388 standards. Then fixed carbon was calculated by subtracting the sum of moisture matter, volatile matter and ash content from 100 by using Equation 5.

$$
\text { Fxed carbon content }(\%)=100-(\% \text { moisture }+\% \text { volatile }+\% \text { ash })
$$

\subsection{Ultimate analysis}

The Ultimate analysis of the coal sample was determined by the using EA 1112 flash CHNS/O analyzer in Addis Ababa University, Department of Chemistry. The working conditions of an analyzer with carrier gas flow rate of $120 \mathrm{ml} / \mathrm{min}$, reference flow rate $100 \mathrm{ml} / \mathrm{min}$, oxygen flow rate $250 \mathrm{ml} / \mathrm{min}$, furnace temperature of $900^{\circ} \mathrm{C}$, oven temperature of $75^{\circ} \mathrm{C}$ and oxygen injection time was for 5 seconds. For the determination of CHNS, the Flash EA smart Analyzer was operated with the dynamic flash combustion of the powder sample. $3 \mathrm{mg}$ of powder samples 
were weighed in a tin container that was introduced into the combustion reactor through the Thermo Scientific MAS plus Auto-sampler in the presence of oxygen. After combustion, the resulting gases were conveyed by a helium flow to a layer filled with copper, then swept through a column that provides the separation of the combustion gases. Finally Thermal Conductivity Detector (TCD) was used for detecting the results.

\subsection{Determination of nitrogen content by Kjeldahl method}

$2.00 \mathrm{~g}$. of prepared coal sample was weighed and put into Kjeldahl digestion flask with $20 \mathrm{ml}$ of sulfuric acid with two Kjeldahl tablets as a catalyst. Then the flask was slightly heated in an inclined position adjusted at $390{ }^{\circ} \mathrm{C}$ and allowed to boil for $6 \mathrm{hrs}$. During the digestion, the $\mathrm{NH}_{4}^{+}$ion $\left(\left(\mathrm{NH}_{4}\right)_{2} \mathrm{SO}_{4}\right)$ was formed and the mixture was diluted with $100 \mathrm{ml}$ of distilled water for cooling. To neutralize the solution and convert the $\mathrm{NH}^{+}$ion into an ammonia gas excess of $50 \mathrm{ml}(50 \%(\mathrm{w} / \mathrm{v}))$ of sodium hydroxide was added. Then the flask was connected to the Kjeldahl distillation apparatus followed by boiling and condensation of the gas with $70 \mathrm{ml}(4 \%(\mathrm{w} / \mathrm{v}))$ of boric acid was added that followed by 4-7 drops of Tashoro's (MR and BCG) indicator in the receiving flasks for 5 min. Finally, the distillate was titrated against $0.1 \mathrm{M}$ hydrochloric acid. The same procedure was repeated for the blank solution and the percentage nitrogen $(\% \mathrm{~N})$ was calculated using the formula in Equation 6 (Ryemshak et al.2016).

$$
\text { Nitrogen in }(\%)=\frac{\mathrm{V} 2(\mathrm{ml})-\mathrm{V} 1(\mathrm{ml}) \times 0.1 \mathrm{M} \times \frac{14.007 \mathrm{~g}}{\mathrm{~mol}}}{\text { Weight of sample taken }(\mathrm{g})} \times 100
$$

\subsection{Determination of sulphur with Eschka methods}

$1 \mathrm{~g}$ of coal samples was weighed in a porcelain crucible and mixed with $3 \mathrm{~g}$ of Eschka mixtures ( $2 \mathrm{~g}$ of magnesium oxide and $1 \mathrm{~g}$ of anhydrous sodium carbonate). The mixture was covered with another $1 \mathrm{~g}$ of Eschka mixture that uses for preventing the loss of sulfur as sulfur dioxide. Then the crucible was put in a cold muffle furnace and heated gradually at $800^{\circ} \mathrm{C}$ for 60 minute. The compounds of Sulphur that evolved during combustion were reacted with Eschka mixture under oxidized conditions; both were converted to Sodium Sulphate and Magnesium Sulphate. Then the product was digested by dilute $1 \mathrm{M}$ of $\mathrm{HCl}$ solution with intermittent stirring for $45 \mathrm{~min}$. The digested solution was filtered into $400 \mathrm{ml}$ beakers and three drops of methyl oranges were added until the color was turned to neutral. Next, the sample was heated to boiling and $10 \mathrm{ml}$ of $10 \% \mathrm{BaCl}_{2}$ was gradually added while stirring in continuous boiling for 30 minute. Finally, the solution was filtered after cooling down by thoroughly washing with hot water and the residue $\mathrm{BaSO}_{4}$ formed was burned at $500^{\circ} \mathrm{C}$ and weighed (Speight 2015; Samila et al.2020; Adekunle et al.2015). The formed $\mathrm{BaSO}_{4}$ was used to calculate the sulfur content in coal samples by using Equation 7.

$$
\text { Sulfur }(\%)=\frac{32}{233} \times \frac{\text { Weight of Baso } 4 \text { formed }(g)}{\text { Weight of sample taken }(g)} \times 100
$$

\subsection{Oxygen content}

The percentage of oxygen in the given sample was determined by differentiating another ultimate analysis from 100 and oxygen content was calculated as Equation 8.

Oxygen $\%=100-(C \%+H \%+N \%+S \%+A \%+M \%$ 


\subsection{Determination of calorific value}

Approximately $1 \mathrm{~g}$ of powder coal sample was weighed in nickel crucible and placed in a bomb by supporting over the ring. Then Oxygen supply was purged across the valve into the bomb until the pressure was reached 25-30 atm for completing the combustion. Then the bomb was placed in the nickel bucket of calorimeter that was filled with $2000 \mathrm{ml}$ of distilled water. After the power was switched on the initial temperature was recorded and when bucket temperature was equilibrated with the bomb temperature the bomb was fired. Then the maximum temperature was recorded from the reader and the bomb was removed from the bucket and the knop valve was open gradually to release the residual gas pressure before attempting to remove the cap. All unburned pieces of fuse wire from the bomb electrode were removed, straightened and measured their combined length in $\mathrm{cm}$ to know the net amount of wire burned. Finally, the bomb washing was titrated with a standard sodium carbonate solution using a methyl orange indicator. Then the gross heat combustion was calculated as Equation 9.

$$
\mathrm{GCV}=\frac{(\mathrm{tW}-\mathrm{e} 1-\mathrm{e} 2-\mathrm{e} 3)}{\mathrm{m}}
$$

$\mathrm{GCV}=$ Gross calorific value in Btu/lb.

$\mathrm{t}=$ the temperature change

$\mathrm{W}=$ energy equivalent of calorimeter in $\mathrm{cal} /{ }^{\circ} \mathrm{C}$

$\mathrm{e}_{1}=$ correction in calories for the heat of formation of nitric acid $\left(\mathrm{HNO}_{3}\right)$

$=(\mathrm{ml}$ of standard alkali solution used in acid titration $)$ if $0.0709 \mathrm{~N}$ alkali was used for the acid titration

$\mathrm{e}_{2}=$ correction in calories for the heat of formation of sulfuric acid $\left(\mathrm{H}_{2} \mathrm{SO}_{4}\right.$

$\mathrm{e}_{3}=$ correction in calories for the heat of combustion of fuse wire

$\mathrm{m}=$ mass of coal sample taken in $\mathrm{gm}$

\subsection{Scanning electron microscopy (SEM)}

Scanning electron microscopy analysis using a field emission microscope model (Inspect F50) was used to determine the nature of surface morphology coal samples.. Small amounts of powder sample were put on the sample holder covered with a conductive carbon tape. The operating parameters of SEM were adjusted with a voltage of $15.00 \mathrm{kV}$, a Working distance of $11.4 \mathrm{~mm}$ and different magnification power.

\subsection{Fourier transform Infrared spectroscopy (FTIR)}

The constituent surface functional groups of an original raw and treated coal sample were separately determined by using FT-IR (Perkin Elmer spectrum, USA) with the wavenumber ranges of $4000-400 \mathrm{~cm}^{-1}$. The final results were collected and reported by transmittance versus wavenumbers (Liu et al.2018).

\subsection{X-ray diffraction (XRD)}

The crystalline structures and mineral matters were identified in both raw and floated samples by using (XRD, SHIMADZU-7000, Japan) equipped with $\mathrm{Cu} \mathrm{K} \alpha$ radiation $(\lambda=1.5406 \AA)$ and $2 \theta$ ranges from 2 to $70^{\circ}$ with continuous scanning. The operating parameters are voltage was at $40 \mathrm{kV}$, the current was $30 \mathrm{~mA}$ and speed of scanning rate was $3.0 \mathrm{deg} / \mathrm{min}(\mathrm{Qu}$ et al.2015). 


\section{Results and discussion}

\subsection{Optimized parameters}

The parameters used during floatation process are to be optimized like particle size, feed rate, dosages of reagents (diesel oil and n-octanol), pulp density, and impeller speed. The optimization of these working parameters in this study was done based on the principles of one variable at a time (OVAT). In this study, the maximum mineral removal efficiency was quantified as the response, together with feed rate, a dosage of collectors and frother, impeller speed and particle size were provided as the main factors. At this optimized condition, the maximum yield of floated coal obtained were $77.5 \%$ of Achibo, $73.5 \%$ of Sombo and $67.9 \%$ of Dabaso (Table 1). The recovery coal yield obtained from this experiment was comparable with the result obtained after optimization parameters at impeller speed of $2000 \mathrm{rpm}$, diesel oil $(10 \mathrm{~kg} / \mathrm{t}), \operatorname{MIBC}(500 \mathrm{~g} / \mathrm{t})$ and particle size at $125-74 \mu \mathrm{m}$ with ash contents of treat coal particle was $8.27 \%$ and the yields of coal recovered was $80.7 \%$ (Chen et al.2018)

Table 1: Optimum values for floatation of the coal

\begin{tabular}{ll}
\hline Parameters & An optimized value of the conditions \\
\hline Feed rate in $(\mathrm{g})$ & 90 \\
Pulp density $(\mathrm{gm} . / \mathrm{L})$ & 30 \\
Impeller speed in $(\mathrm{rpm})$ & 2800 \\
Particle size in $(\mu \mathrm{m})$ & $125-63$ \\
Collector dosage $($ diesel oil) in $(\mathrm{ml})$ & 5 \\
Frother dosage (n-octanol) in $(\mathrm{ppm})$ & 40 \\
Yield of concentrate $(\%)$ & $77.5 \%$ of Achibo, 73.5\% of Sombo and 67.9\% of Dabaso \\
\hline
\end{tabular}

\subsection{Floatation results}

As shown in Figure 3 a, the floatation of the coal particle was seen after the addition of collector (diesel oil) at the conditioning time of ( $\mathrm{t}=1 \mathrm{~min}$.). The formation of big bubbles was seen and particles were not attached to the surface of the oily bubbles.). But after the addition of n-octanol as frother and increasing the conditioning time to 5 minutes, the bubble was stabilized and small in size as seen in Figure $\mathbf{3}$ b. The formed foam particles were skimmed off and filtered by using Whatman filter paper to separate the residue from its solution as shown in Figure $\mathbf{3} \mathbf{c}$. The filtrate of both tailing (residue) and concentrate (foam) was dried and taken for characterization.

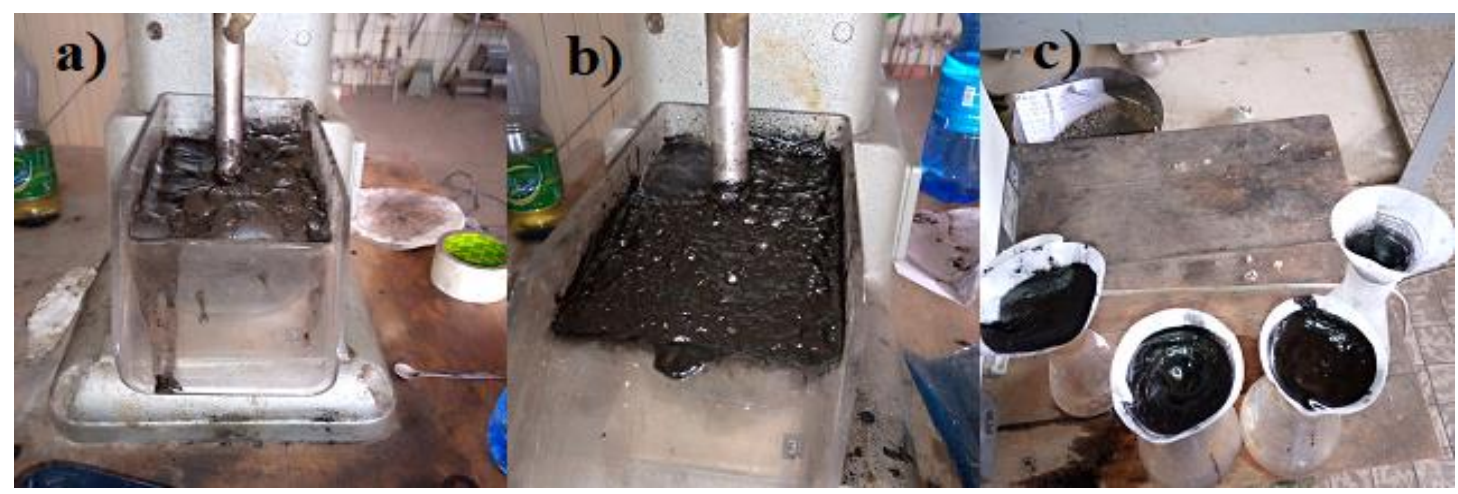

Fig.3 Froth floatation procedures and resulting coal particles 


\subsection{Inherent moisture content}

The obtained results of moisture content for raw coal were ranged from $11.81 \%$ to $20.27 \%$ and the moisture content of (treated) floated coal ranges from $8.12 \%$ to $14.02 \%$ with a total average value of $11 \%$ as shown in Fig. 4. The Sombo streams have the highest amounts of moisture content but Dabaso streams have the smallest moisture contents as compared with other remaining streams. Therefore the highest value of moisture implies that lower carbon contents that lead to lower heating value and higher costs for transportation and storage (Wakuma and Assaba 2017).

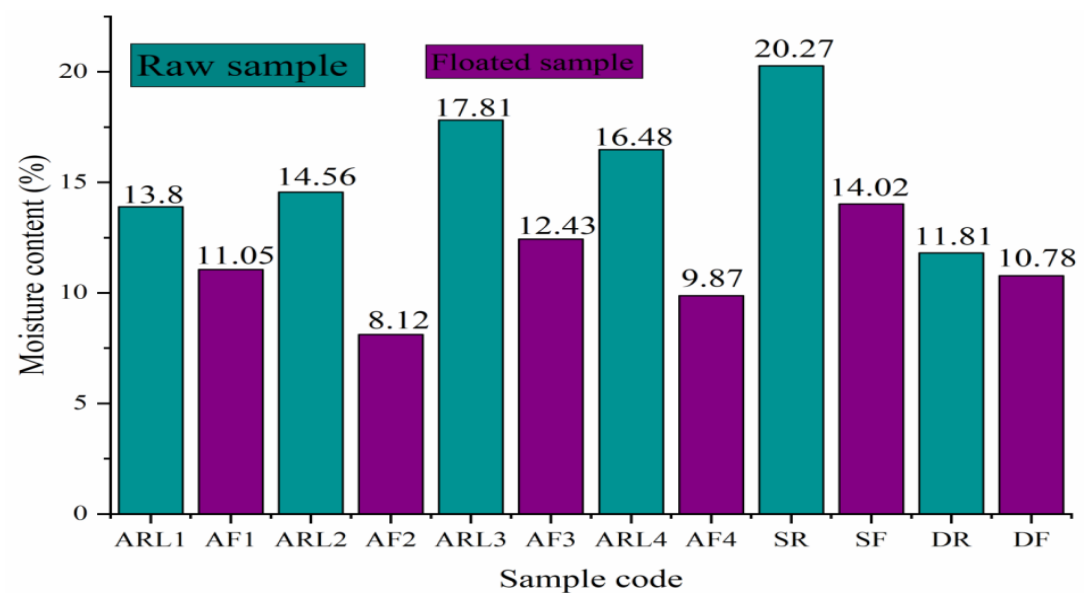

Fig. 4 Moisture contents vs. Sample code

\subsection{Volatile matter}

The experimental result obtained from volatile matter for raw coal samples that were collected from three sampling sites (Achibo, Sombo and Dabaso) was ranging from $22.74 \%-34.85 \%$. But the volatile matter for a treated sample was below $30.64 \%$. The Achibo stream has the highest volatile matter with both raw and floated samples as described in Table 2. Accordingly, as reported by (Habtezgi 2001) results indicated that the obtained results of volatile matter are ranged from $15.4 \%$ to $45 \%$ and the results have shown that the values of volatile matter lie in ranges of $22.3 \%$ to $38.1 \%$. The higher amount of the volatile matter in coal specifies that the lower rank of the coal and increasing volatile matter also increased the quantities of combustible gases, which directly decreases the amount of fixed carbon and consequently decreases the heating value of the coal. Finally, in this study, the floatation technique is used for treatment of coal to reduce the volatility of the coal and to increase the staying time at storage rooms.

Table 2 Amount of volatile matter obtained from experimental results

\begin{tabular}{llr}
\hline Sample Code & \multicolumn{2}{c}{ Volatile matter of sample } \\
\cline { 2 - 3 } & Untreated(raw) sample & Treated \\
& & 30.64 \\
ARL1 & 34.85 & 28.93 \\
ARL2 & 32.57 & 29.48 \\
ARL3 & 33.61 & 21.92 \\
ARL4 & 22.74 &
\end{tabular}




\subsection{Ash content}

Ash is an impurity substance that will not be burned. The ash content that was obtained from the experiment on raw coal is ranging from $22.47 \%$ to $36.58 \%$ as stated in Fig. 5. The Achibo second layer has the highest value of ash content from the three sampling sites which was $36.58 \%$ and the lower ash content was recorded on Achibo fourth layer that was $22.47 \%$. The consequence of increasing ash content led to reducing the burning capacity, affects combustion efficiency, increases handling cost, and causes large slagging. The amount of ash content and its behavior at high temperatures affect the design and type of ash handling system that is employed in the coalutilization process. At high-temperature coal ash become sticky and eventually forms molten slag. The outcomes of increasing the amounts of ash content in coal lead to decreased quality or rank because volumes of high impurity reduce the coal efficiency. According to Ahmed (1998) the ash content was ranged from $10.2 \%$ to $54.6 \%$ and the majority of the sample was attaining less than $38 \%$.

As shown in Fig. 2 the ash content of the treated coal sample was reduced with ranges of 7.49\% to $13.62 \%$. This confirms that the ash content of the Achibo treated coal sample is much more reduced after treatment when compared with others that possessed relatively high fixed carbon and calorific value.

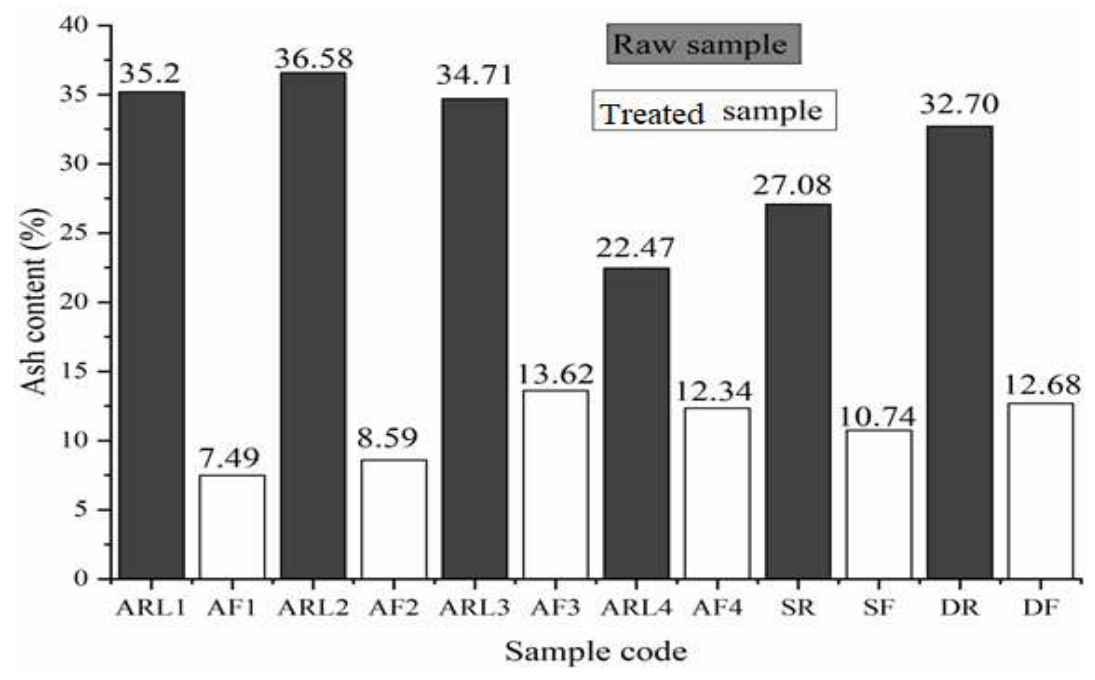

Fig.5 Ash contents for raw and floated coal sample

The ash content was related to moisture and volatile matter that was shown in Table 3, Achibo streams have high amounts of ash and volatile matters but lower in moisture content. But Sombo and Dabaso streams have moderate amounts of ash and volatile matter. Therefore this all proximate parameter was reduced in treated coal and the ash content of three study areas was highly reduced that can be ignited easily and extremely reactive in combustion. Generally, the relationship of proximate value and the increasing amount of moisture content is leading to increasing the ash and volatile matters. Therefore the presence of moisture content was decreased relatively with the volatility of the coal increases, and moisture increases with volatility decreases. 
Table 3: The relation between Moisture, Volatile matter and Ash content

\begin{tabular}{ccccccc}
\hline Sample code & \multicolumn{2}{c}{ Ash content $(\%)$} & \multicolumn{2}{c}{ Moisture content $(\%)$} & \multicolumn{2}{c}{ Volatile matter (\%) } \\
\cline { 2 - 7 } & Raw & Treated & Raw & Treated & Raw & Treated \\
\hline ARL1 & 35.2 & 7.49 & 13.8 & 11.05 & 34.85 & 30.64 \\
ARL2 & 36.58 & 8.59 & 14.56 & 8.12 & 32.57 & 28.93 \\
ARL3 & 34.71 & 13.62 & 17.81 & 12.43 & 33.61 & 29.48 \\
ARL4 & 22.47 & 12.34 & 16.48 & 9.87 & 22.74 & 21.92 \\
SR & 27.08 & 10.74 & 20.27 & 14.02 & 28.44 & 25.33 \\
DR & 32.70 & 12.68 & 11.81 & 10.78 & 30.84 & 24.74 \\
\hline
\end{tabular}

\subsection{Fixed carbon content}

The Fixed carbon tells a rough estimation of the heating value of the coal. The amount of fixed carbon content for raw coal that was obtained from the experimental result was found in the ranges of $23.15 \%$ to $38.31 \%$ as described in Table 4. All raw coal samples were showing less than $40 \%$ of the fixed carbon content which implies that lowering the carbon number highly affected the heating efficiency of the coal. From the studied area Achibo fourth layer was the highest amounts of fixed carbon as compared to others, but the first layers of Achibo and Sombo streams have lower amounts of fixed carbon. The lowering amount of fixed carbon was due to the coal was highly affected by ash, volatile matter, and moisture content that presented in it.

The fixed carbon for the treated coal sample was obtained after beneficiation experiments that were in the ranges of $44.47 \%$ to $55.87 \%$ as shown in Table 4. From three studying areas, lower layers of Achibo has shown more carbon content and Achibo third layers have low carbon than all other areas. The upgrading of the fixed carbon in lower layers was due to the depth of the burial increases with increasing the ranks of coal and decreasing the inorganic matter, which leads to increasing the carbon number of that coal. Due to the highest fixed carbon observed in Achibo streams, a lead to the calorific value was also higher than the other sites. Therefore, increasing the fixed carbon increase of heating value and decrease the ash contents. Finally from the observed experimental value of Achibo-Sombo coal, the value of the fixed carbon content for a raw sample was majorly in the ranges $23.85 \%$ to $38.31 \%$, but after treatment, the ranges of fixed carbon contents raised to $55.87 \%$.

Table 4 The amounts of fixed carbon content for raw and floated coal sample

\begin{tabular}{lllllllll}
\hline \multirow{2}{*}{$\begin{array}{l}\text { Sample } \\
\text { code }\end{array}$} & \multicolumn{2}{l}{ Moisture content $(\%)$} & \multicolumn{2}{c}{ Volatile matter $(\%)$} & \multicolumn{2}{c}{ Ash content $(\%)$} & \multicolumn{2}{c}{ Fixed carbon $(\%)$} \\
\cline { 2 - 8 } ARL1 & Raw & Treated & Raw & Treated & Raw & Treated & Raw & Treated \\
\cline { 2 - 8 } ARL2 & 13.8 & 11.05 & 34.85 & 30.64 & 35.2 & 7.49 & 23.85 & 50.82 \\
ARL3 & 14.56 & 8.12 & 32.57 & 28.93 & 36.58 & 8.59 & 24.29 & 54.36 \\
ARL4 & 17.81 & 12.43 & 33.61 & 29.48 & 34.71 & 13.62 & 33.81 & 44.47 \\
SR & 20.48 & 9.87 & 22.74 & 21.92 & 22.47 & 12.34 & 38.31 & 55.87 \\
DR & 11.87 & 14.02 & 28.44 & 25.33 & 27.08 & 10.74 & 34.21 & 52.81 \\
\hline
\end{tabular}




\subsection{Carbon and Hydrogen content}

The carbon content of the study area for the sample is ranging from $38.90 \%$ to $44.54 \%$ and for the treated coal sample is ranging from $44.12 \%$ to $61.06 \%$ as shown in Table 5. The ultimate carbon is differing from proximate fixed carbon, during the treatment of coal under high temperature some carbon contents are lost as volatile in the case of fixed carbon. Therefore lowering ultimate carbon in coal indicated that the coal was categorized under the low grade.

Table 5 Carbon and Hydrogen content of the coal

\begin{tabular}{lllll}
\hline Sample code & \multicolumn{2}{l}{ Carbon content $\mathrm{n}(\%)$} & \multicolumn{2}{l}{ Hydrogen content (\%) } \\
\hline \multirow{3}{*}{ ARL4 } & Untreated (raw) & Treated (floated) & Untreated (raw) & Treated (floated) \\
\cline { 2 - 5 } SR & 44.54 & 61.06 & 5.28 & 2.98 \\
& 39.90 & 44.12 & 4.85 & 3.26 \\
\hline
\end{tabular}

The hydrogen content in the study area for the raw coal sample is ranging from $4.85 \%$ to $5.28 \%$ and treated coal hydrogen content was reduced to ranges from $2.98 \%$ to $3.26 \%$. The higher amount of hydrogen content affects the combustion behavior of the coal and is the characteristic of low-grade coal. But the low value of hydrogen in coal has shown that the coal showed the characteristic of higher grades.

\subsection{Nitrogen content}

The obtained nitrogen content from the experimental value was in the range of $1.22 \%$ to $1.44 \%$ for the raw coal sample and after treatment the nitrogen content was reduced and ranged from $0.52 \%$ to $0.92 \%$ as described in Table 6. Achibo first layers sample showed the highest amount of nitrogen contents, it was closer to organic materials of decomposed plants. The presence of nitrogen in coal samples will pollute the environment by releasing nitrogen oxides into the atmosphere in certain combustion conditions. It also, decreases the heating values of the coal and as the grade of the coal increases (matures) the extractable nitrogen content was decreased. Low-grade coal has high amounts of nitrogen content (Ryemshaket et al.2015).

Table 6 The Nitrogen content of the coal

\begin{tabular}{lll}
\hline Sample code & \multicolumn{2}{c}{ Nitrogen content (\%) } \\
\cline { 2 - 3 } & Untreated (raw) & Treated (floated) \\
\hline ARL1 & 1.44 & 0.69 \\
ARL2 & 1.35 & 0.92 \\
ARL3 & 1.22 & 0.83 \\
ARL4 & 1.28 & 0.79 \\
SR & 1.33 & 0.64 \\
DR & 1.31 & 0.52 \\
\hline
\end{tabular}




\subsection{Sulphur content}

The investigated results of Sulphur content in raw coal samples are ranging between $0.57 \%$ to $1.9 \%$ and after treated the sulfur content is reduced to the ranges $0.25 \%$ to $0.92 \%$ as described in Table 7. The first layers of the Achibo site contain the highest amounts of sulfur content than other sites, but the third layers of these sites contain the lowest amounts of sulfur. The high amount of sulfur in coal was lowering the heating ability of the combusted coal due to the formation of high ash of sulfur contents in the forms of barite $\left(\mathrm{BaSO}_{4}\right)$, galena $(\mathrm{PbS})$ and gypsum $\left(\mathrm{CaSO}_{4} \cdot 5 \mathrm{H}_{2} \mathrm{O}\right)$. So the higher sulfur led to causes emission of $\mathrm{SO}_{2}$ gas that responsible for pollution of the environments that cause acid rain and lung cancer on human health (Ryemshaket et al.2015; Adekunle et al.2016). Then beneficiation of coal by floatation was used to minimize the amounts of sulfur content in the coal sample which leads to increases in the calorific values and qualities of the coal.

Table 7 Sulfur content obtained in coal samples

\begin{tabular}{lllll}
\hline Sample code & \multicolumn{2}{l}{ Weight of $\mathrm{BaSO}_{4}$ obtained (gm.) } & \multicolumn{2}{l}{ Sulfur contents (\%) } \\
\cline { 2 - 5 } & untreated (raw) & Treated (floated) & Untreated (raw) & Treated (floated) \\
\hline ARL1 & 0.1383 & 0.0299 & 1.9 & 0.41 \\
ARL2 & 0.0422 & 0.0182 & 0.58 & 0.25 \\
ARL3 & 0.0415 & 0.0327 & 0.57 & 0.45 \\
ARL4 & 0.0859 & 0.0669 & 1.18 & 0.92 \\
SR & 0.0488 & 0.0240 & 0.67 & 0.33 \\
DR & 0.0859 & 0.0277 & 1.18 & 0.38 \\
\hline
\end{tabular}

\subsection{Oxygen content}

The oxygen content of the present study area for raw coal samples is ranging from 5.9 to $15.77 \%$ and for treated coal samples is ranging from 12.58 to $16.89 \%$ as shown in Table 8. The expected value of oxygen content for treated coal would be lower than that of untreated coal sample, due to highly reduced ash content and increment of carbon number in the lower range. Therefore values of oxygen content for treated coal samples are higher than that of untreated coal in Sombo streams.

Table 8 Results for ultimate analysis of coal samples

\begin{tabular}{|c|c|c|c|c|c|c|c|c|c|c|}
\hline \multirow{2}{*}{$\begin{array}{l}\text { Sample } \\
\text { code }\end{array}$} & \multicolumn{2}{|c|}{ Carbon (\%) } & \multicolumn{2}{|c|}{ Hydrogen (\%) } & \multicolumn{2}{|c|}{ Sulphur (\%) } & \multicolumn{2}{|c|}{ Nitrogen (\%) } & \multicolumn{2}{|c|}{ Oxygen (\%) } \\
\hline & Raw & Treated & Raw & Treated & Raw & treated & Raw & Treated & Raw & Treated \\
\hline ARL4 & 37.54 & 61.06 & 5.28 & 2.98 & 1.18 & 0.25 & 1.28 & 0.92 & 15.77 & 12.58 \\
\hline SR & 39.90 & 54.12 & 4.85 & 3.26 & 0.67 & 0.33 & 1.33 & 0.64 & 5.9 & 16.89 \\
\hline
\end{tabular}

\subsection{Calorific value}

The experimental value of calorific value for both raw and floated coal samples is determined by using the Adiabatic Bomb calorimeter in the central laboratory of the Geological Survey of Ethiopia. As shown in Table 9, the obtained 
result of the calorific value for the raw sample is ranging from 5838.46 to $8111.29 \mathrm{Btu} / \mathrm{lb}$. for Achibo from first to fourth layers. But after the treatment, the calorific value is ranging from 10285.25 to $11756.63 \mathrm{Btu} / \mathrm{lb}$. for Achibo site. The Sombo and Dabaso site area also increases in their calorific value to $9833 \mathrm{Btu} / \mathrm{lb}$. and $9438.12 \mathrm{Btu} / \mathrm{lb}$. respectively from its untreated types of coal. This shows that the beneficiation by froth flotation method is appropriate approach to increase calorific value of mentioned sites. Specifically, the calorific value of the top layers of Achibo, Sombo and Dabaso liberated very low amounts of heat; for containing high impurity materials and ash which affect the combustion efficiency of the coal. Top layer is also accounted for lower carbon contents and high amounts of volatile matter than the remaining layers. Even though top layers of the sample sites after treatment show low calorific values, Achibo top layer has better quality than other sites. On the hand, the results from Table 9, prove that as the burial depth of Achibo increases the organic carbon content increases which is responsible for an increase in the calorific value. The obtained results confirm that quality of a coal increases when depth increases (Ahmed 2008)

Table 9 Calorific values of raw and floated coal samples.

\begin{tabular}{lllllll}
\hline Sample code & \multicolumn{5}{c}{ Calorific value } \\
& \multicolumn{2}{c}{ Cal/gm. } & \multicolumn{2}{c}{ MJ/kg (x by factors of 4.18 } & \multicolumn{2}{c}{ Btu/lb.(x by factor of 1.8 } \\
\cline { 2 - 7 } & Untreated & Treated & Untreated (raw) & Treated & Untreated & \multicolumn{1}{c}{$\begin{array}{c}\text { Treated } \\
\text { (floated) }\end{array}$} \\
& (raw) & (floated) & & 23.88 & 7045 & 10285.25 \\
& 3913.89 & 5714.03 & 16.36 & 24.81 & 5838.46 & 10697.17 \\
ARL1 & 3243.59 & 5942.87 & 13.56 & 26.72 & 8007.85 & 11505.83 \\
ARL2 & 4448.81 & 6392.13 & 18.6 & 27.30 & 8111.29 & 11756.63 \\
ARL3 & 4506.25 & 6531.46 & 18.84 & 22.88 & 9531.49 & 9833 \\
SR & 5295.27 & 5462.78 & 22.13 & 21.92 & 8955.25 & 9438.12 \\
DR & 4975.2 & 5243.4 & 20.8 & & & \\
\hline
\end{tabular}

The obtained proximate value is given rough estimation information of liberating heat value. The obtained value of fixed carbon in Achibo of third and fourth layers was higher than other sites so they liberated more calorific value. Then after treatment, the calorific value of the coal is increased due to an impure material is separated with the help of chemical reagents. In Achibo streams due to increments of the burial depth than all other sitting areas the amounts of fixed carbon was highly changed from its value of $38.31 \%$ to $55.87 \%$ in lower layers that led to more coal particle was attached on the surface of the reagents and the more calorific value was recorded by changing from 8111.29 Btu/lb. to11756.63 Btu/lb. The calorific value of the Sombo raw sample is increased from the value $9531.49 \mathrm{Btu} / \mathrm{lb}$. to the treated value of $9833 \mathrm{Btu} / \mathrm{lb}$. These increments of heating value were due to the change of fixed carbon from $34.21 \%$ to $52.81 \%$ and the reduction of ash content from its value of $27.08 \%$ to $10.74 \%$. Generally, the relationships between fixed carbon and ash with calorific value have a direct relation. The increasing of fixed carbon increases the calorific value and decreasing the ash contents, but the fixed carbon decreases the calorific value is decreasing with increasing ash content of the coal as shown in Fig. 5 


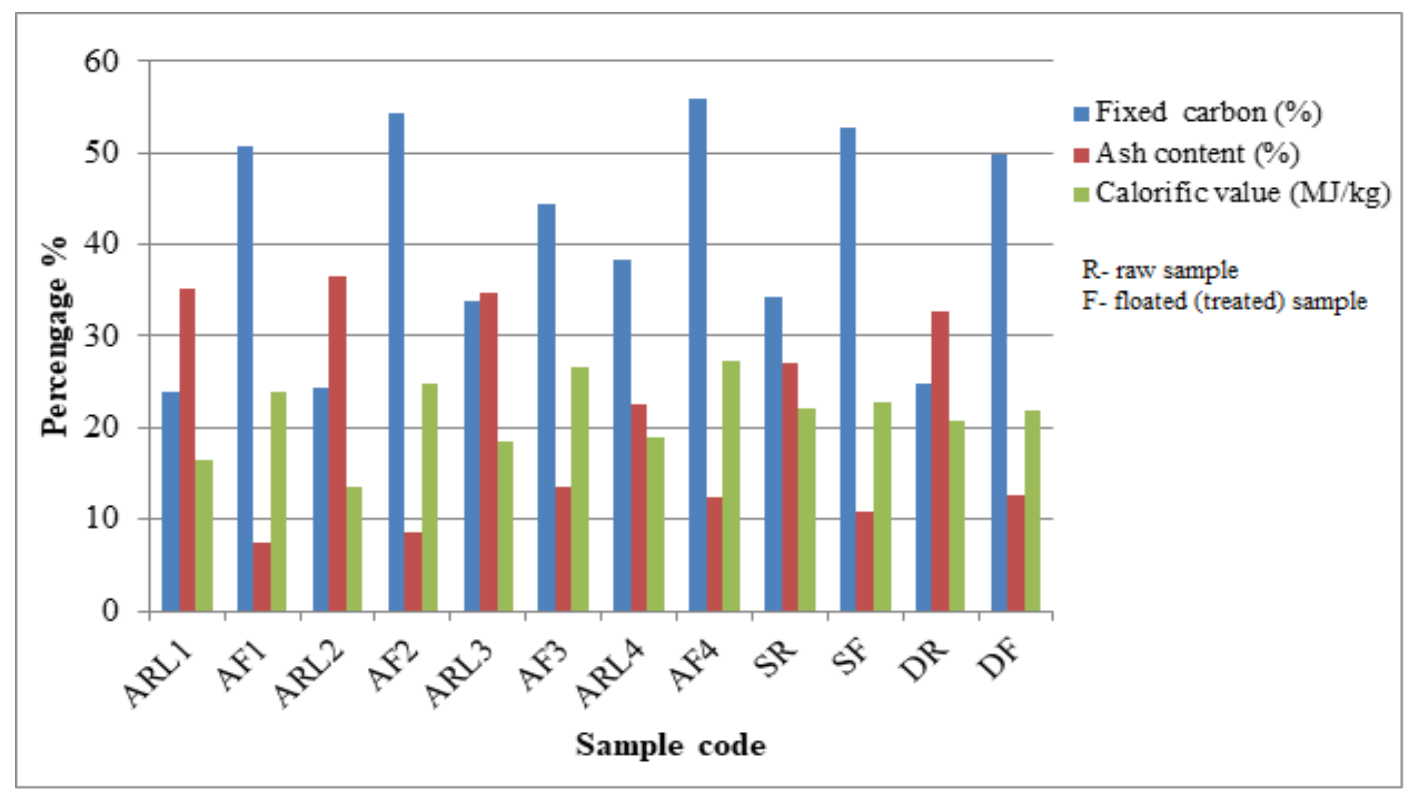

Fig. 3 Relationship between calorific value with proximate analysis

\subsection{Coal grade determination}

ASTM D-388 is used for the classification of coal grades or ages based on the amounts of fixed carbon and calorific values. As shown in Table 10 of this work, the gross calorific value and fixed carbon results of raw samples from sampled sites are used to classify the grade of raw coal that was found in grade between lignite B and subbituminous B. According to the obtained results Sombo and Dabaso sites have better calorific value than Achibo site. Although the two sites viz Sombo and Dabaso did not show significant improvement in calorific value after treatment, Achibo site layers shown remarkable change in it. Generally, the gross calorific value (Btu/lb.) is increased from its lower value to higher and this enables to grade the coal in the range of sub-bituminous B and high volatile bituminous $\mathrm{C}$ after treatment for four layers of Achibo Site. Although raw coal from top layers of Sombo and Dabaso valleys have been graded under sub-bituminous B and C with higher calorific value, they did not show significant change in calorific value after treatment when they compared with layers of Achibo. This could be justified for presence of high impurities in the layers.

Table 10 Coal Grade Determination.

\begin{tabular}{|c|c|c|c|c|c|c|}
\hline \multirow[t]{2}{*}{$\begin{array}{l}\text { Sample } \\
\text { code }\end{array}$} & \multicolumn{2}{|c|}{ Fixed carbon $(\%)$} & \multicolumn{2}{|c|}{$\begin{array}{l}\text { Calorific value } \\
\text { Btu/lb. }\end{array}$} & \multicolumn{2}{|c|}{ Grade (groups) of coal } \\
\hline & Raw & Treated & Raw & Treated & Raw & Treated \\
\hline ARL1 & 23.85 & 50.82 & 7045 & 10285.25 & Lignite A & Sub-bituminous B \\
\hline ARL2 & 24.29 & 54.36 & 5838.46 & 10697.17 & Lignite B & Sub-bituminous A \\
\hline
\end{tabular}




\begin{tabular}{lllllll} 
ARL3 & 33.81 & 44.47 & 8007.85 & 11505.83 & Lignite A & High volatile bituminous C \\
ARL4 & 38.31 & 55.87 & 8111.29 & 11756.63 & Sub-bituminous C & High volatile bituminous C \\
SR & 34.21 & 49.91 & 9531.49 & 9833 & Sub-bituminous B & Sub-bituminous B \\
DR & 24.98 & 52.81 & 8955.36 & 9438.12 & Sub-bituminous C & Sub-bituminous C \\
\hline
\end{tabular}

\subsection{Surface Morphology}

The surface morphology of coal particles for the raw and floated sample was revealed in Figure 6 (a) and (b). The SEM result of the surface of raw coal particles indicated by having large holes and crack formation that increases the surface roughness. So the holes on the surface will adsorb more collector reagent rather than spreading on the surface of the coal particles that decreases the performance of the floatation process. However; after floatation, the surface of the coal demonstrated several physical and chemical alterations by decreasing the holes and cracks of the particle. The SEM image after treatment indicates that the particles are more compacted and homogeneity of particles is increased. This might be due to the removal of impurities and the increment of carbon content in a sample.
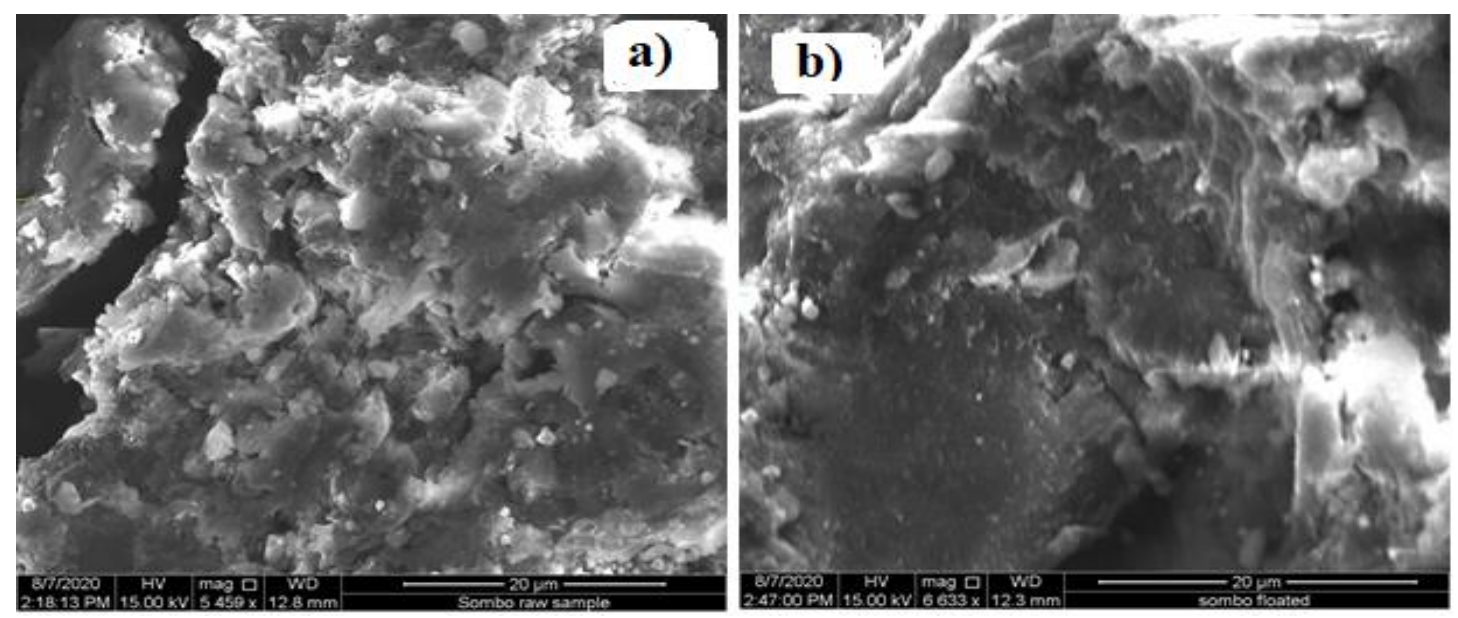

Fig.4 SEM image of raw (a) and treated coal (b)

\subsection{Functional Groups}

FT-IR analysis was made to understand the nature of the bonds and to recognize various functional groups which exist on the surface coal sample. Figure 7 shows the FT-IR spectra of coal surface and the peaks at $2842 \mathrm{~cm}^{-1}$ and $2922 \mathrm{~cm}^{-1}$ correspond to $\mathrm{C}-\mathrm{H}$ stretching of alkane. The peaks at $1594 \mathrm{~cm}^{-1}$ and $3696 \mathrm{~cm}^{-1}$ are representing $\mathrm{C}=\mathrm{C}$ stretching of aromatic hydrocarbon of benzene rings and $\mathrm{O}-\mathrm{H}$ stretching of an alcohol group respectively as shown in Table 11. The spectra of ash forming minerals in coal analysis were illustrated in the fingerprint region such as the peaks at $526 \mathrm{~cm}^{-1}$ and $462 \mathrm{~cm}^{-1}$ are corresponding to aromatic pairs of sulfide $-\mathrm{SH}$ and $\mathrm{Fe}_{2} \mathrm{~S}$ respectively. To summarize, the results of FTIR confirm that the intensity of the $\mathrm{C}-\mathrm{H}$ and $\mathrm{C}=\mathrm{C}$ stretching are increased which may indicate an increase of carbon contents in treated sample (Roya et al. 2020; Zhu et al. 2020; Yang et al.2020) 
Table 11 The characteristic of FT-IR coal surface functional groups

\begin{tabular}{llll}
\hline Wavenumbers $\left(\mathrm{cm}^{-1}\right)$ & Functional groups & Compound class & Intensity \\
\hline 684 & & & \\
913 & $\mathrm{C}=\mathrm{C}$ bending & Alkene & Strong \\
1034 & O-H bend & Carboxylic acids & Medium \\
1372 & S=O stretching & Sulfoxide & Strong \\
1450 & S=O stretching & Sulfonate & Strong \\
1594 & C-H bending & Alkane & Medium \\
& C=C stretching vibration & Aromatic hydrocarbon on a benzene & Strong \\
1617 & & ring & \\
2842 & C=C stretching & $\alpha, \beta$ unsaturated ketone & Strong \\
& C-H stretching & Alkane & Medium \\
2922 & N-H stretching & Amine salt & Strong \\
3696 & C-H stretching & Alkane & Medium \\
\hline
\end{tabular}

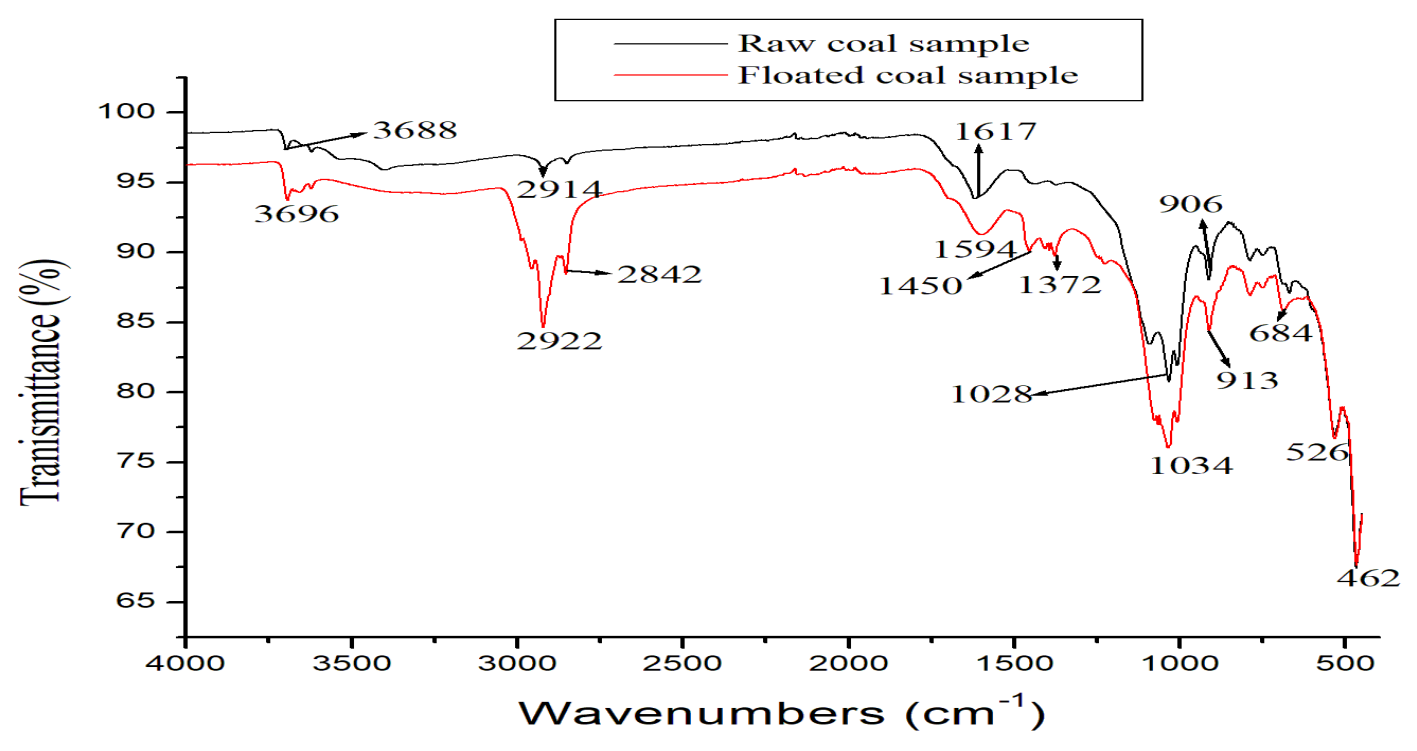

Fig.5 FT-IR spectra coal sample before and after treatment

\subsection{Crystal structures and mineral Identification}

The crystalline structure and mineral compositions for both raw and floated coal particles are examined by using XRD as shown in Figure 8. The peaks at 2-theta values of 12.55 and $22.14^{\circ}$ were recognized as the (310) and (528) planes of $\mathrm{SiO}_{2}$ respectively (JCPS card no. 027-0605 Silicon oxide (Quartz)). But the peaks at 2-theta values of 26, 33 and $47^{\circ}$ were corresponding to (449), (185) and (139) shows the planes of $\mathrm{FeS}_{2}$ respectively (JCPS card no. 0421340 Iron Sulfide (Pyrite)). Whereas the peaks at 2-theta values of 24 and $56^{\circ}$ were corresponding to (487) and (232) 
the planes of $\mathrm{TiO}_{2}$ respectively (JCPS card no. 021-1272 Titanium oxides (Anatase, syn)). Hence, the XRD result of both samples shows that the coal particle contained the minerals of quartz, pyrite and anatase.

The peaks of the pyrite minerals at floated samples were minimized which shown that the removal of sulfide forms ash and shows slightly shifts of the peaks on floated coal samples. XRD results confirm that quartz ( $\mathrm{SiO} 2)$, pyrite $(\mathrm{Fe} 2 \mathrm{~S})$ and anatase (TiO2) which are responsible for ash increment in the sampled coal are common and the results are similar with work of (Chen et al.2018). In addition to this the XRD image proves that the minerals content is decreased after treatment.

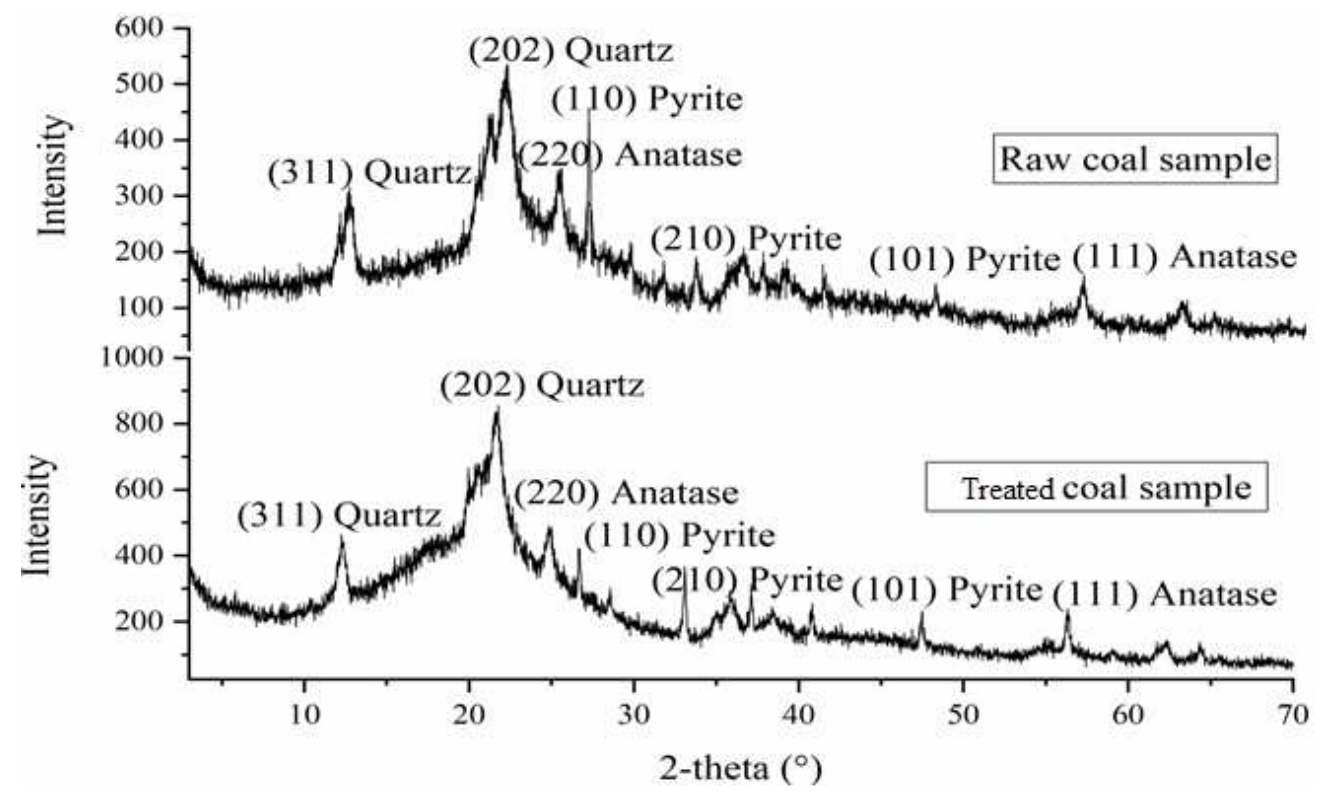

Fig. 6 XRD Analysis of both raw and treated coal samples

\section{CONCLUSION}

The Achibo-Sombo coal deposit is treated by physiochemical beneficiation via floatation method to increases the calorific value by using diesel oil and n-octanol to obtain the coal recoveries of $77.5 \%$ yield of Achibo, $73.5 \%$ yield of Sombo and $67.9 \%$ yield for Dabaso. The amount of ash and sulfur content of the area is highly reduced from its maximum value of $36.58 \%$ of second layers of raw Achibo to a minimum value of $7.49 \%$ of first layers of Achibo treated sample. The grades of raw coal in the studying area fell under lignite B coal to sub-bituminous B groups with calorific value ranged from 5838.46 to $9531.49 \mathrm{Btu} / \mathrm{lb}$. But after treatment of the samples the grades of the coal are ranging under sub-bituminous $B$ to high volatile bituminous $C$ with the calorific values ranging from 9438.12 to $11756.63 \mathrm{Btu} / \mathrm{lb}$. The results of FTIR confirm that the intensity of the $\mathrm{C}-\mathrm{H}$ and $\mathrm{C}=\mathrm{C}$ stretching are increased which is a clear indication of an increase of carbon contents in treated samples. The SEM image after treatment indicates that the particles are more compacted and homogeneity of particles is increased. This might be due to the removal of impurities and the increment of carbon content in a sample. The XRD obtained result confirms that the quartz $(\mathrm{SiO} 2)$, pyrite $(\mathrm{Fe} 2 \mathrm{~S})$ and anatase $(\mathrm{TiO} 2)$ which are responsible for ash increment in the sampled coal are reduced 
after treatment. Finally, the overall finding of this study confirms that the calorific value of Achibo-Sombo coal is upgraded to the expected level of the desired application by the froth floatation technique implemented.

\section{Abbreviation}

A, Ash content; BCG, Bromocresol green indicator; Btu/lb., British thermal unit per pound; ASTM, American society for testing and materials; $\mathrm{e}$, correction in calories for heat of formation of nitric acid $\left(\mathrm{HNO}_{3}\right)$; e2, correction in calories for heat of formation of sulfuric acid $\left(\mathrm{H}_{2} \mathrm{SO}_{4}\right)$; e3, correction in calories for heat of combustion of fuse wire; $\mathrm{Hg}$, gross calorific value; JCPS, Joint Committee on Power Diffraction Standards; m, mass of coal sample taken in gm; M, Moisture content; MR, Methyl red; PR china, Peoples Republic china;V1, Volume of hydrochloric acid consumed for blank; V2, Volume of hydrochloric acid consumed for sample; $t$, temperature changes of bomb calorimeter; w, energy equivalent of calorimeter in cal $/{ }^{\circ} \mathrm{C}$;

\section{Conflicts of interest/Competing interests}

The authors have no conflict of interest

\section{References}

Abraham K (2018) Characterization and Evaluation of Mush Valley Coal for Its Application as a Domestic Energy Source. MSc, Thesis, Addis Ababa Institute of Technology, School of Chemical and Bio-Engineering.

Adekunle JO, Ibrahim JS, Kucha EI (2015) Proximate and Ultimate Analyses of Bio-coal Briquettes of Nigerian's Ogboyaga and Okaba Sub-bituminous Coal. Brit J of Appl Sci and Technol, 7(1):114-123.

Ahmed W (2008) Fossil Fuel Energy Resources of Ethiopia. Bulletin Chemical Society of Ethiopia 22(1): 67-84.

Ahmed W (1998) Result of Sub - Surface Exploration for Coal Deposit at Achibo-Sombo (Yayu Illubabor Area). Ethiopia mineral development enterprise (Mineral study and exploration department).

Barma SD (2019) Ultrasonic-Assisted Coal Beneficiation. Ultrasonic- Sonochemistry 50:15-35

Behera SK, Kumari U, Meika BC (2018) A Review of Chemical Leaching of Coal by Acid and Alkali Solution. J of Mining and Metall 54(1):1-24.

Cheng G, Li Z, Ma Z, Cao Y, Sun L, Jiang Z (2019) Optimization of Collector and Its Action Mechanism in Lignite Flotation, Powder Technol 345:182-189.

Chen S, Wang S, Li L, Qu J, Tao X, He H ( 2018) Exploration on the Mechanism of Enhancing Low-Rank Coal Floatation With Cationic Surfactant in the Presence of Oily Collector. Fuel 227:190-198.

Dejene Y (2004) The Utilization of Indigenous Coal as Energy Substitute in Cement Industry. M.Sc.Thesis, Addis Ababa Institute of Technology, Chemical and Bio-Engineering (Process Engineering stream).

Demoze EA (2007) Utilization of Coal in Metal Industries (In Case of Akaki Metal Products Factor). MSc, Thesis, Addis Ababa University, Department of Environmental Engineering 
Habtezgi G (2001) Geological Report on Coal Deposit Extension Investigation around Wittete and Yayu Blocks. Coal - Phosphate Fertilizer Complex Project 1:1-120.

Haftu M, Koka B, Woldearagay K, Abay A (2019) Coal Resource Evaluation And Mine Design Analysis Of Achibo-Sombo Underground Coal Mine, Southwestern Ethiopia. Int J of Earth Sci and Eng 12(1):149-156.

IEA (2019) Coal information overview, Int Energy Agency 53:1689-99.

Ilkwuagwu CS, Uzoegbu MU (2017) The Maiganga Coal Deposit, Bituminous, Sub-Bituminous and Lignite. J of Appl Geol and Geophy (IOSR-JAGG) 5(1): 67-74.

Liu R, Chen Q, Xia H (2018) Study on Pyrolysis Characteristics of Pretreated High-Sodium (Na) Zhundong Coal by Skimmer-Type Interfaced TG-DTA-EI/PI-MS System. Fuel Processing Technology 170:79-87.

Liu X, Wu X, Wang J (2018) Substantial Upgrading of High-Ash Lignite by Hydrothermal Treatment Followed by $\mathrm{Ca}(\mathrm{OH})_{2}$ Digestion / Acid Leaching. Fuel 222:269-277.

Meshram P, Purohit BK, Sinha MK, Sahu SK, Pandey BD (2015) Demineralization of Low Grade Coal. Renewable and Sustain Energy Reviews 41:745-761.

Mishra BK, Das B, Biswal S K, Reddy PSR (2015) Overview of Beneficiation, Utilization and Environmental Issues in Relation to Coal Processing. Proce Indian Nation Sci Acad 81(4):725-737.

Ni C, Bu X, Xia W, Peng Y, Xia G (2018) Effect of Slimes on the Floatation Recovery and Kinetics of Coal Particles. Fuel 220:159-166.

Qu J, Tao X, Tang L, Xiu N, He H (2015) Flotation Characteristics and Particle Size Distribution of Micro-Fine. Proce Eng102:159-166.

Rao Cheepurupalli N, Anuradha B (2019) Proximate and Ultimate Characterization of Coal Samples from Southwestern Part of Ethiopia. Int J of Eng and Advan Technol (IJEAT) 9(2):1643-1648.

Roy SK, Nayak D, Rath SS (2020) A review on the enrichment of iron values of low-grade Iron ore resources using reduction roasting-magnetic separation. Powder Technol 367:796-808.

Ruiz SI, Diez MA, Ruberia F (2019) Coal. Institute of National DelCarbon, INCAR-CSIC, Oviedo, Elsevier, Spain, pp.1-30. http://perso.wanadoo.es/teresapastor/turba.htm

Ryemshak SA, Jauro A, Putshaka JD, Sori RM (2016) Ultimate Analysis of Some Nigerian Coal: Ranking and Suitable Application. Int J of Eng and Appl Sci (IJEAS) 3(10):31-35.

Samila MB, Muhammad BG, Adam AH, Moumouni A, Bello S (2020) Characterization of Coal Obtained from the Sahelian Regions of Nigeria and Niger Republic. J of Appl Sci and Environ Manag 24(2):299-302.

Singh JP (2016) Leaching Characteristics of Coal and Coal Ash. MSc. Thesis, Thermal Engineering, Thepal University, Patiala.

Speight JG (2015) Chemical analysis. In: Speight JG (ed) Handbook of coal analysis, 2nd edn. Wiley, New York, pp. 1-28. https//doi.org/10.1002/9781119037699.ch5

Tian Q, Wang Y, Li. G (2017) Application of Special Collectors and Flotation Column for Beneficiation. Physicochem Probl of Miner Proce 53(1): 553-568.

Wagaw T. (2007) Coal exploration result in Ethiopia (MInistry of mines and energy and Geological survey of Ethiopia) 
Wakuma B, Assaba B (2017) Physicochemical Characterization of Coal and Its Alternative Use as a Source of Energy (In Case of Yayo Coal Mining Industry. J of Environ Sci Toxicol and Food Technol (IOSRJESTFT) 11(5):44-50.

Wen B, Xia W, Sokolovic JM (2017) Recent Advances in Effective Collectors for Enhancing the Floatation of Low Rank / Oxidized Coals. Powd Technol319:1-11.

Yang Z, Gua. F, Xia. Y, XingY, Gui X (2020) Improved Floatability of Low-Rank Coal through Surface Modification by Hydrothermal Pretreatment," J of Cleaner Production 246:1-10.

Zhu XN, Wang DZ, Ni Y, Wang JG, Nia. CC, Yang C, Lyu XJ, Qiu J, Li L (2020) Cleaner Approach to Fine Coal Flotation by Renewable Collectors Prepared by Waste Oil Trans-Esterification. J of Cleaner Production 252:1-7. 


\section{Figures}

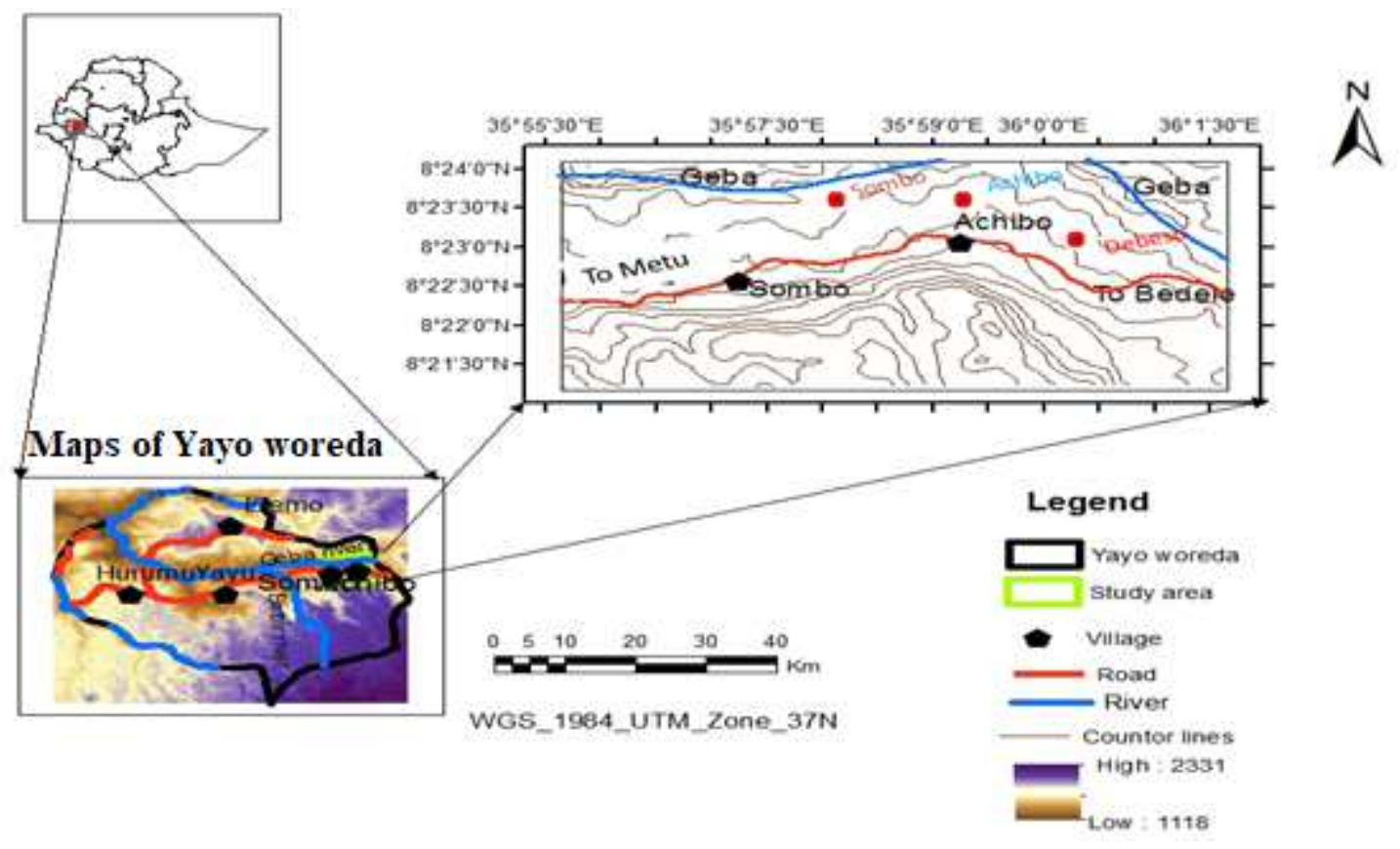

\section{Figure 1}

Location of the study area Note: The designations employed and the presentation of the material on this map do not imply the expression of any opinion whatsoever on the part of Research Square concerning the legal status of any country, territory, city or area or of its authorities, or concerning the delimitation of its frontiers or boundaries. This map has been provided by the authors.
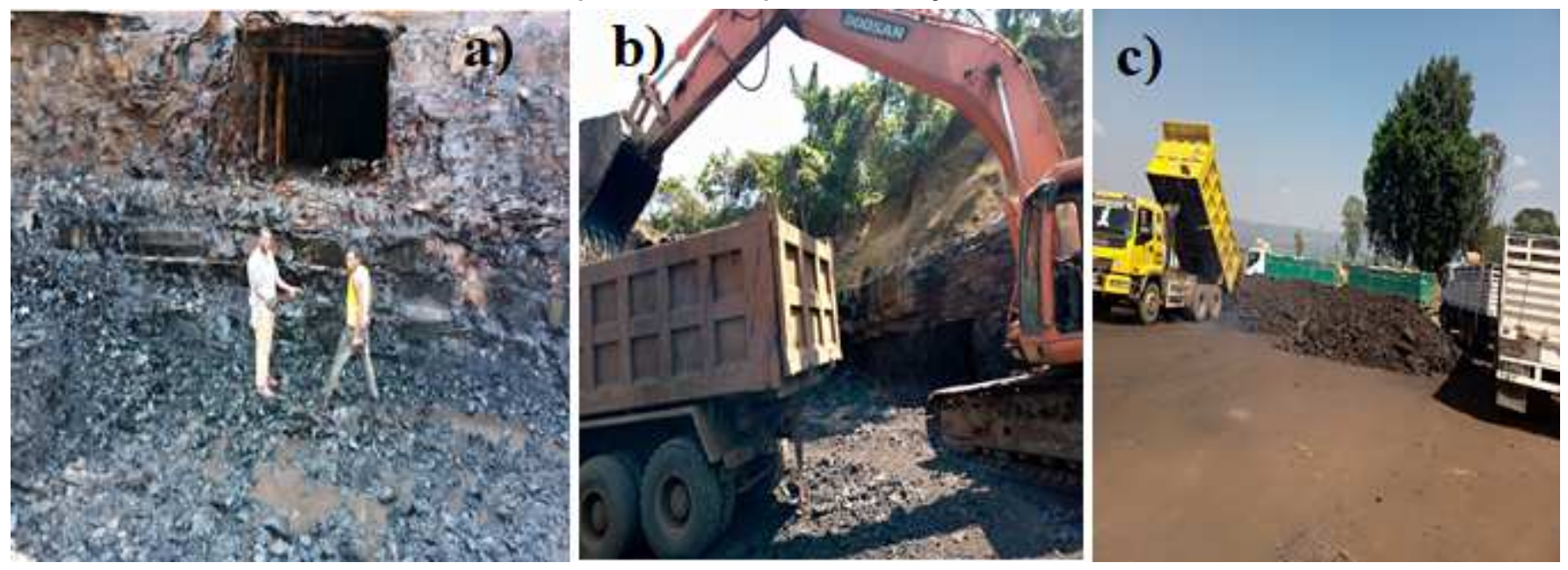

\section{Figure 2}

The sampling area a) exploration site b) surface mining of coal deposits $\mathrm{c}$ ) mined coal 


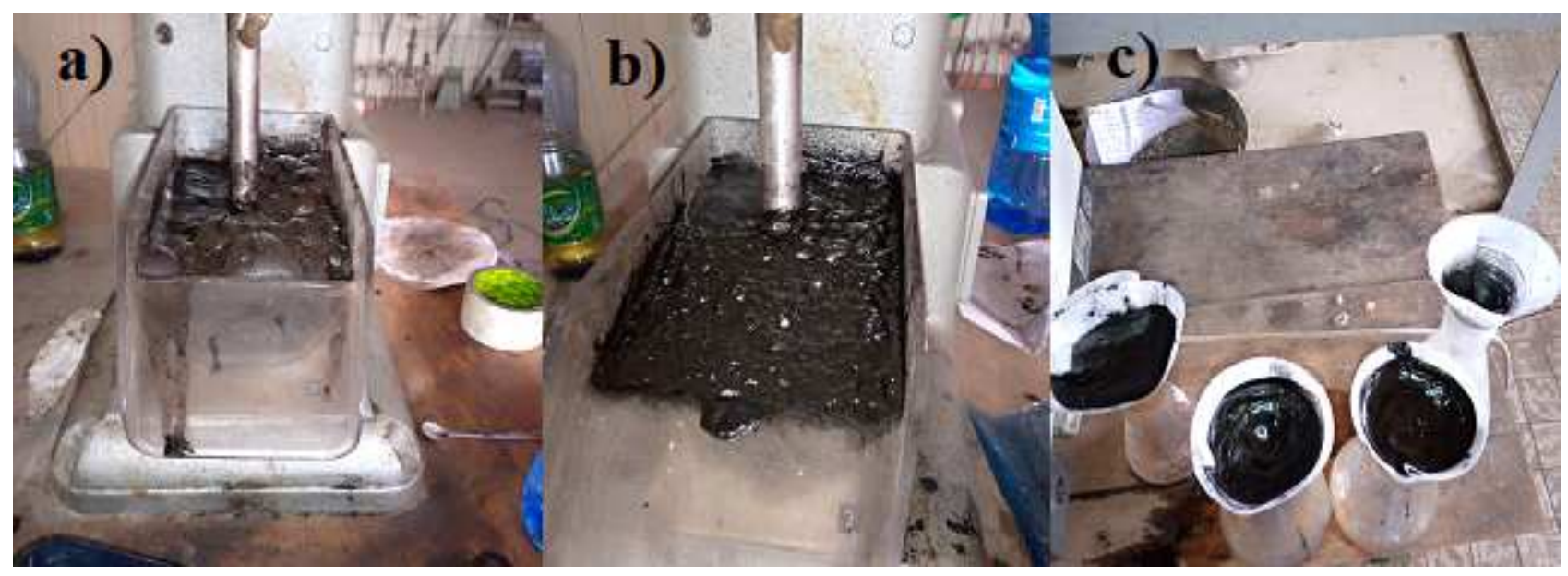

Figure 3

Froth floatation procedures and resulting coal particles

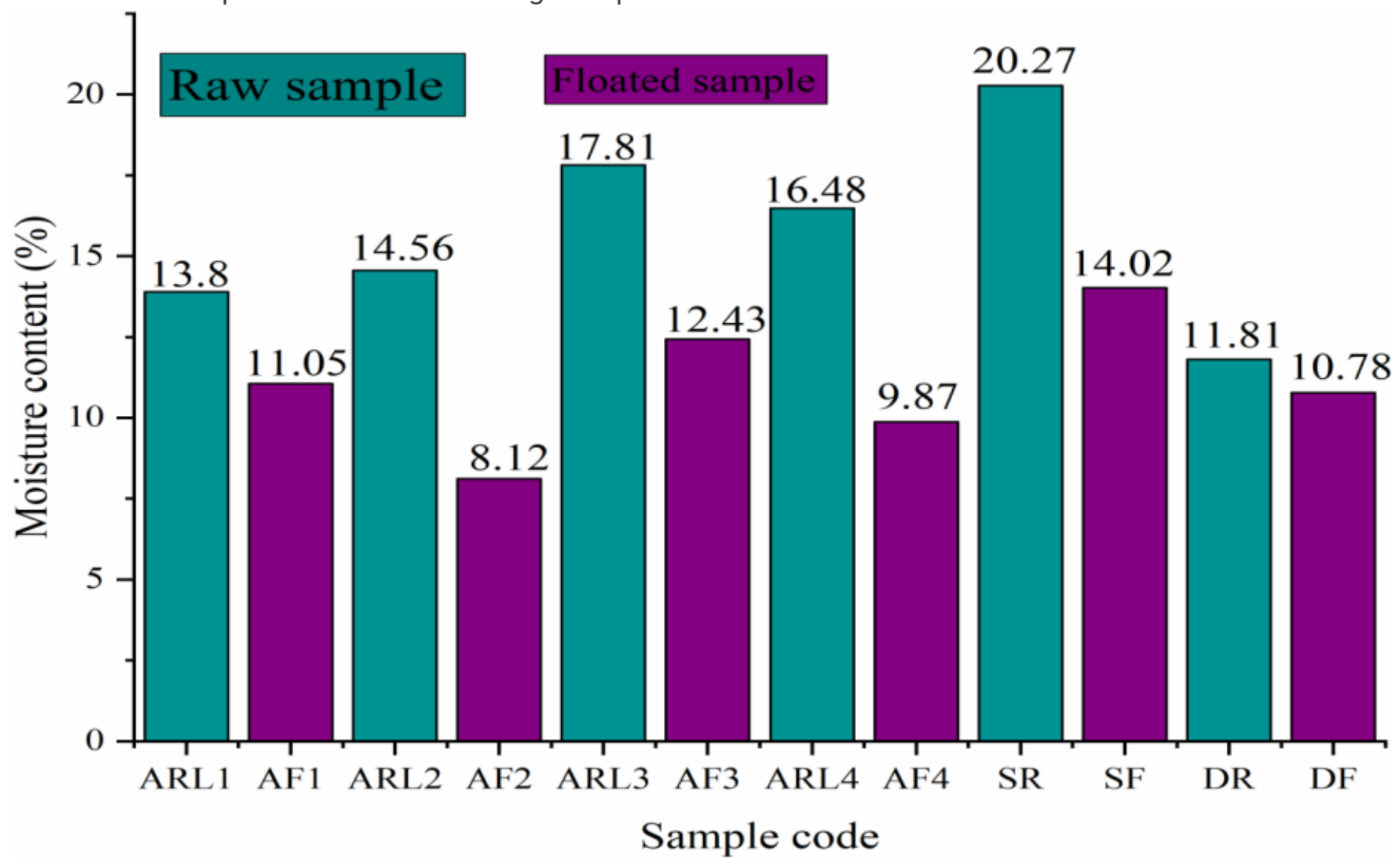

Figure 4

Moisture contents vs. Sample code 


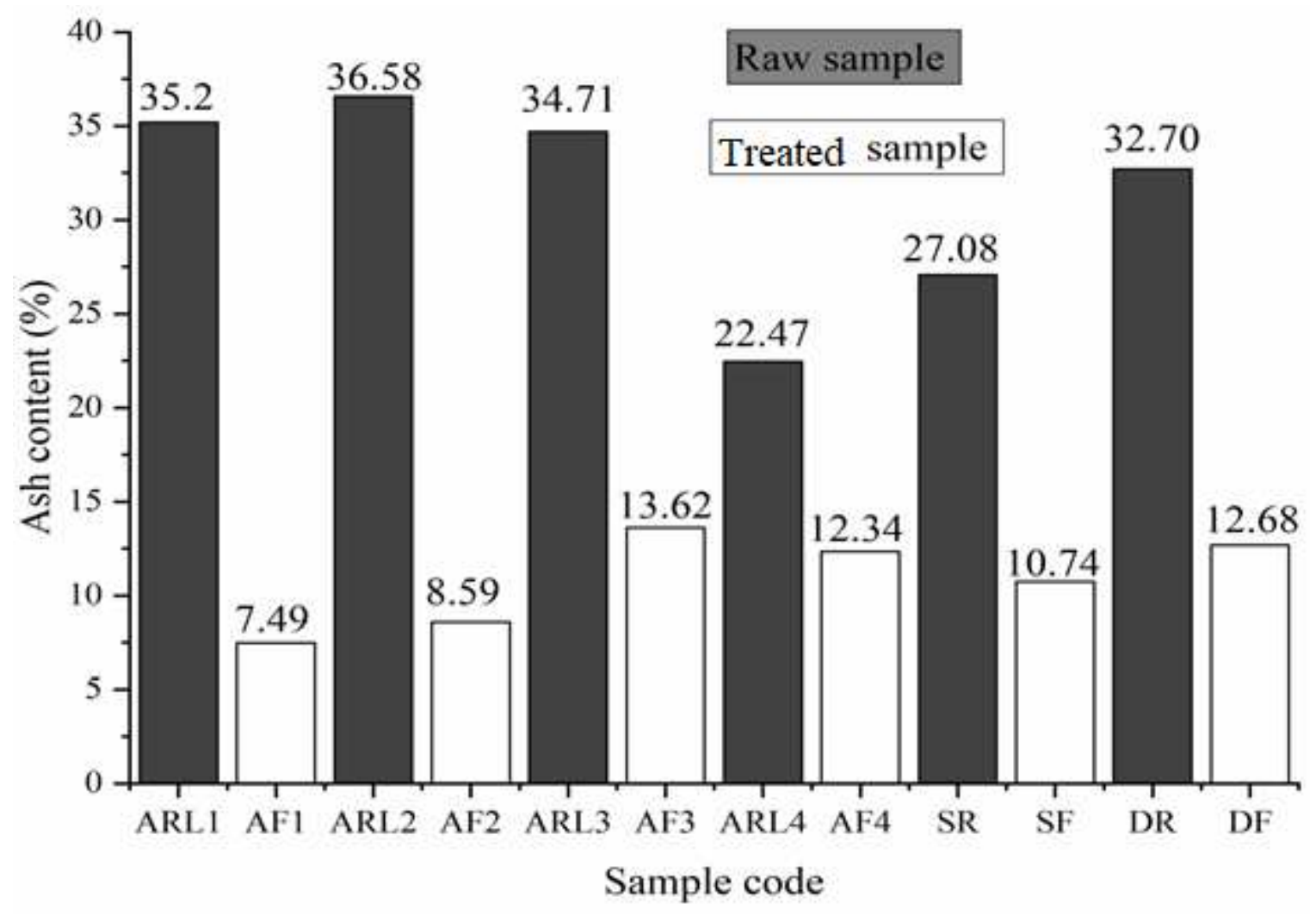

Figure 5

Ash contents for raw and floated coal sample

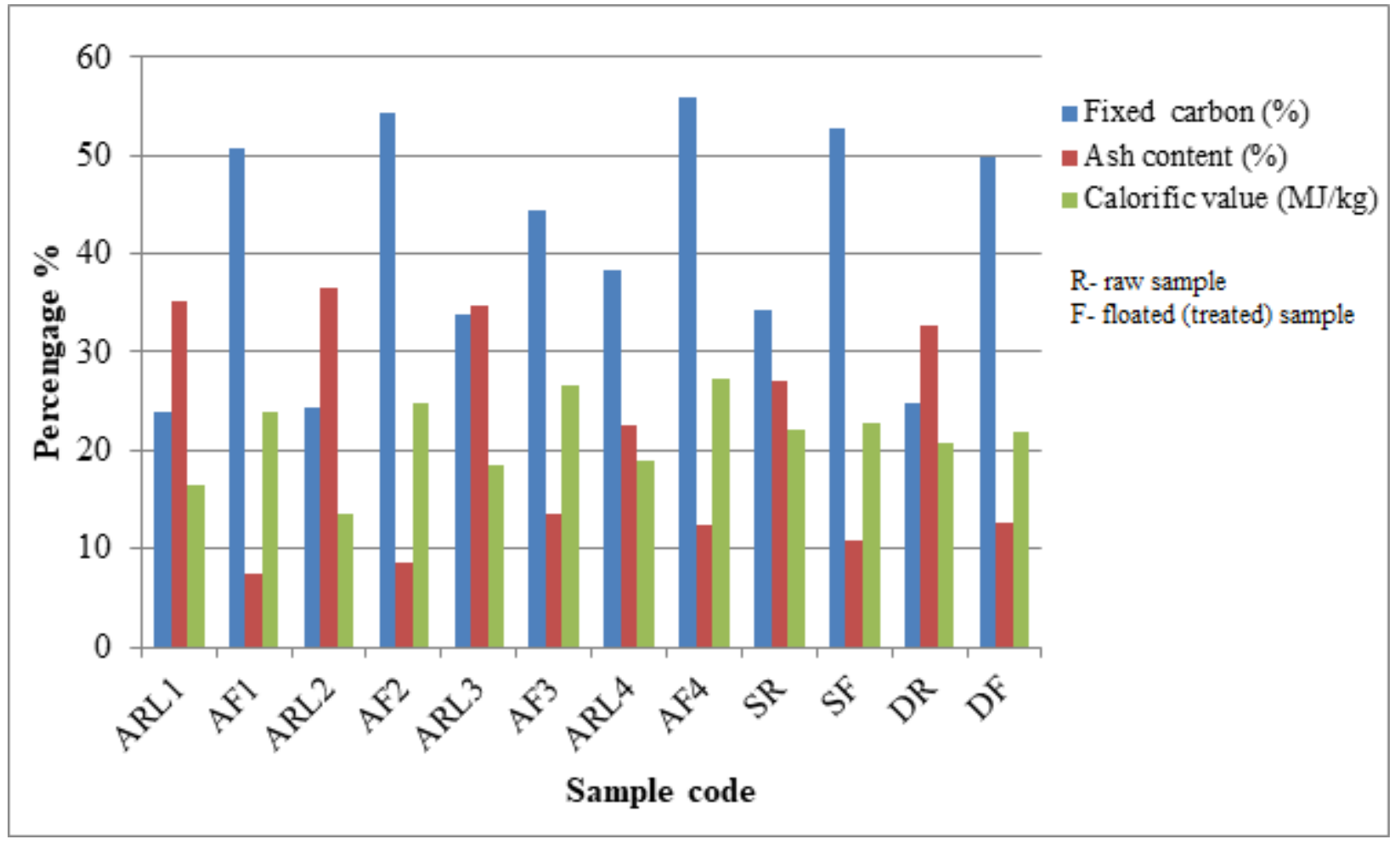

Figure 6

Relationship between calorific value with proximate analysis 

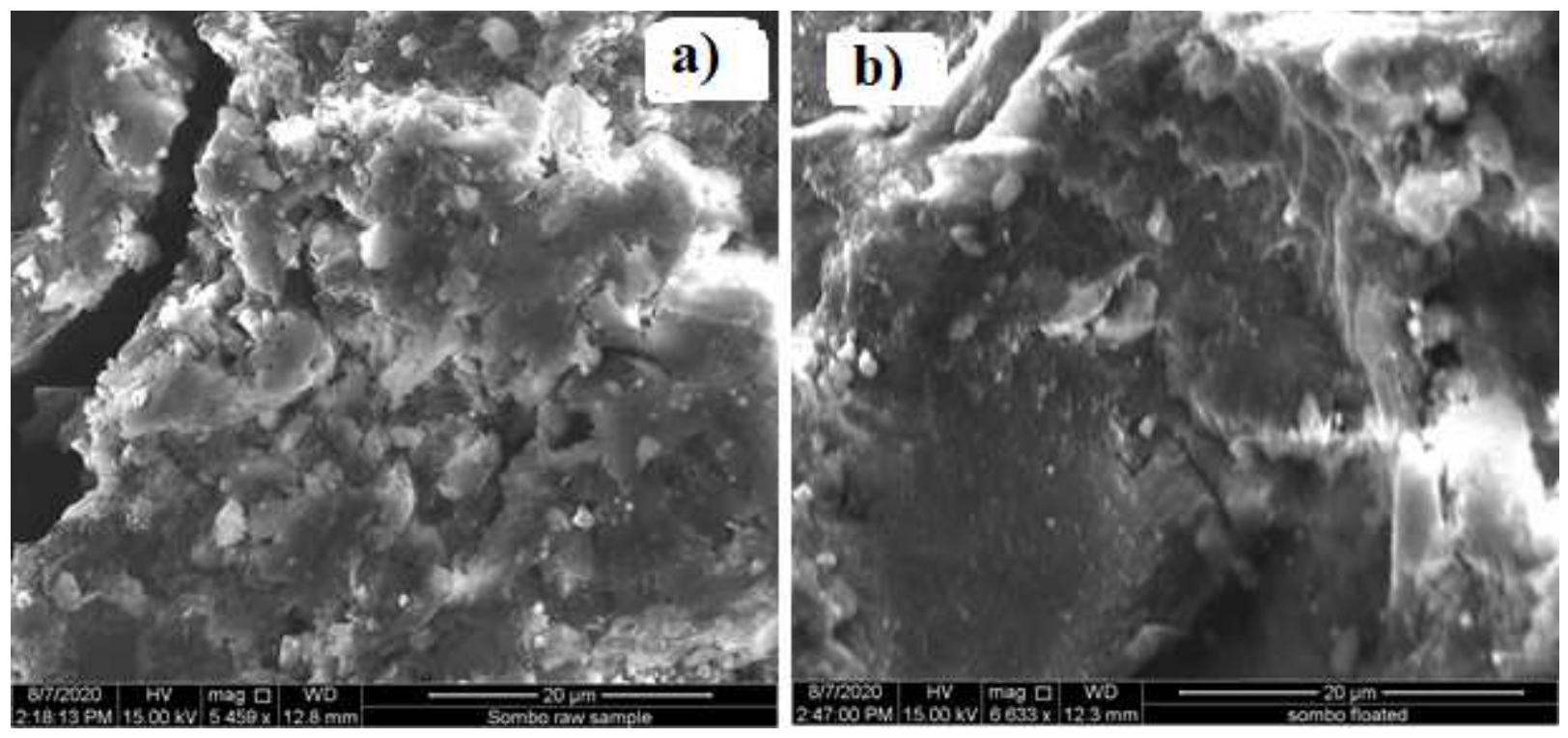

Figure 7

SEM image of raw (a) and treated coal (b)

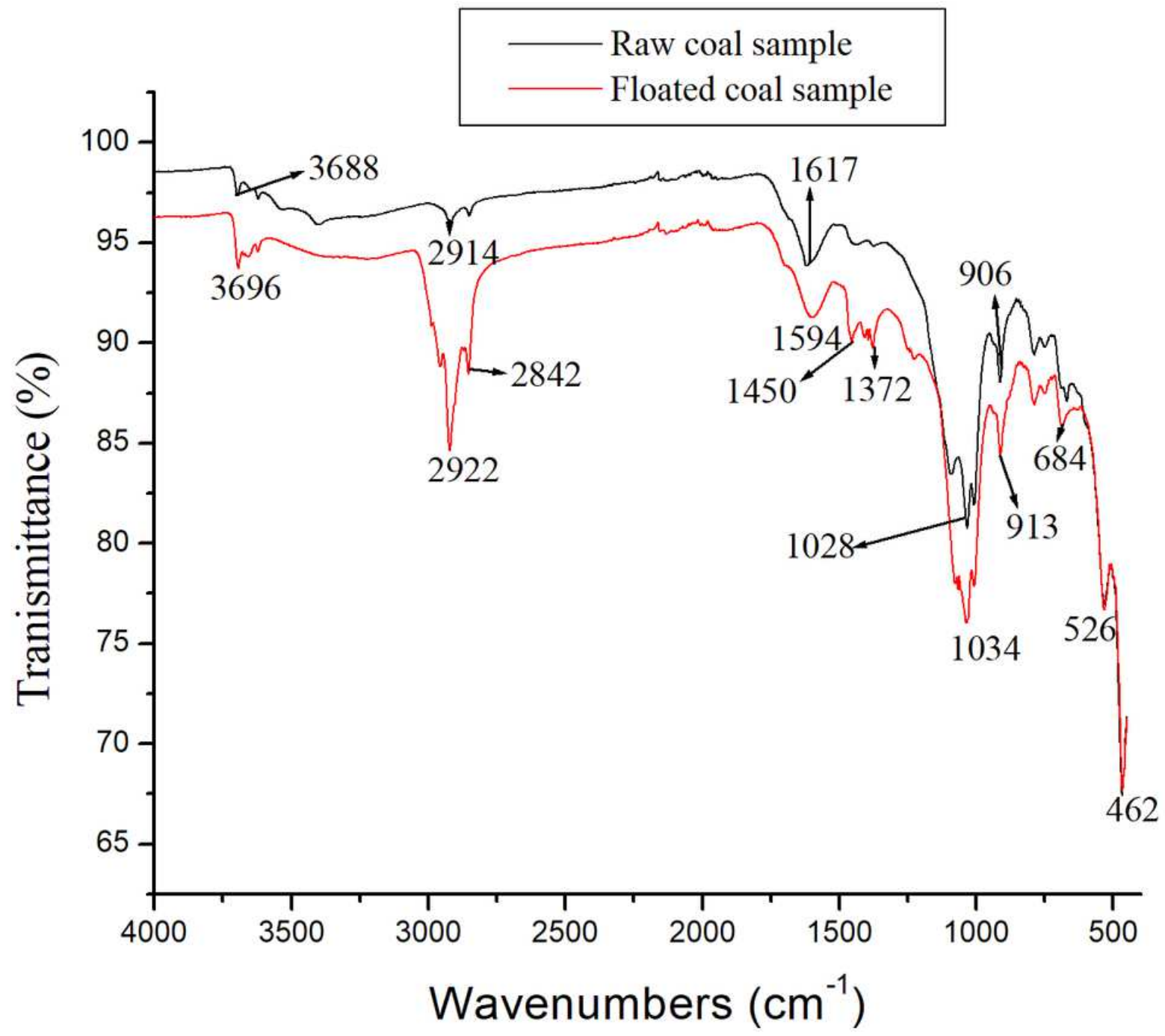


Figure 8

FT-IR spectra coal sample before and after treatment

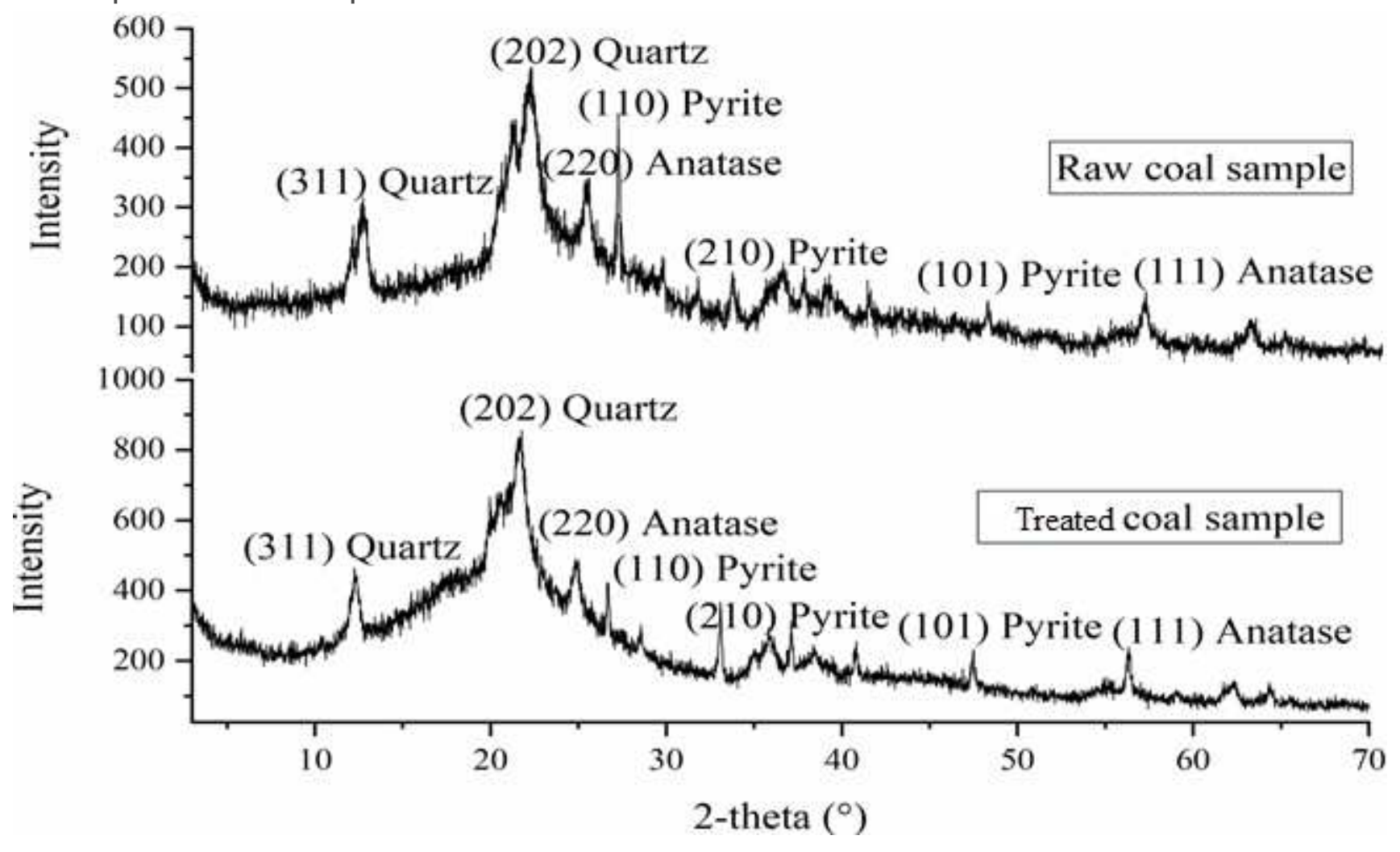

Figure 9

XRD Analysis of both raw and treated coal samples 